Review

\title{
Regulation of Calcitriol Biosynthesis and Activity: Focus on Gestational Vitamin D Deficiency and Adverse Pregnancy Outcomes
}

\author{
Andrea Olmos-Ortiz, Euclides Avila, Marta Durand-Carbajal and Lorenza Díaz * \\ Department of Reproductive Biology, National Institute of Medical Sciences and Nutrition Salvador \\ Zubirán, Vasco de Quiroga No. 15, Tlalpan 14000, Mexico City, Mexico; \\ E-Mails: nut.aolmos@gmail.com (A.O.-O.); euclides.avilac@incmnsz.mx (E.A.); \\ mdurand65@gmail.com (M.D.-C.)
}

* Author to whom correspondence should be addressed; E-Mail: lorenzadiaz@gmail.com; Tel.: +525-54-87-09-00 (ext. 2417).

Received: 31 October 2014 / Accepted: 16 December 2014 / Published: 9 January 2015

\begin{abstract}
Vitamin D has garnered a great deal of attention in recent years due to a global prevalence of vitamin D deficiency associated with an increased risk of a variety of human diseases. Specifically, hypovitaminosis D in pregnant women is highly common and has important implications for the mother and lifelong health of the child, since it has been linked to maternal and child infections, small-for-gestational age, preterm delivery, preeclampsia, gestational diabetes, as well as imprinting on the infant for life chronic diseases. Therefore, factors that regulate vitamin D metabolism are of main importance, especially during pregnancy. The hormonal form and most active metabolite of vitamin D is calcitriol. This hormone mediates its biological effects through a specific nuclear receptor, which is found in many tissues including the placenta. Calcitriol synthesis and degradation depend on the expression and activity of CYP27B1 and CYP24A1 cytochromes, respectively, for which regulation is tissue specific. Among the factors that modify these cytochromes expression and/or activity are calcitriol itself, parathyroid hormone, fibroblast growth factor 23, cytokines, calcium and phosphate. This review provides a current overview on the regulation of vitamin $\mathrm{D}$ metabolism, focusing on vitamin D deficiency during gestation and its impact on pregnancy outcomes.
\end{abstract}

Keywords: micronutrient; placenta; maternal diet; gestational pathologies 


\section{Vitamin D Synthesis and Metabolism}

UVB radiation from sunlight initiates vitamin D (VD) biosynthesis in the skin by bioconverting 7-dehydrocholesterol to previtamin $\mathrm{D}_{3}$, which is thermally isomerized to $\mathrm{VD}$ 3. VD may also be obtained from the diet to a lesser extent. The nutritional forms of VD include both $\mathrm{VD}_{3}$ (cholecalciferol) from animal origin and $\mathrm{VD}_{2}$ (ergocalciferol) from fungi and plant origin. Once formed in the skin or absorbed in the intestine, VD is released into the circulation and transported by the VD-binding protein (DBP) to the liver, where it is converted by the VD-25-hydroxylase (CYP2R1) into 25-hydroxyvitamin D (calcidiol, 25OHD). Calcidiol is the major vitamin D metabolite present in the circulation and the best indicator of VD nutritional status. Nevertheless, this metabolite is not the active form of VD, and therefore needs further activation by a second hydroxylation step catalyzed by the enzyme 25OHD-1- $\alpha$-hydroxylase (CYP27B1) in order to generate 1,25- $(\mathrm{OH})_{2} \mathrm{D}_{3}$ (calcitriol), which is the hormonal form and most active VD metabolite. CYP27B1 is primarily expressed in the kidney but also may be found in different tissues including the placenta. The bioavailability of calcitriol is tightly regulated to restrict the biological actions of this hormone in target cells while maintaining calcium and phosphate homeostasis, and the enzyme in charge of degrading calcitriol to water-soluble and less active metabolites is the 1,25-(OH)2 $\mathrm{D}_{3}$-24-hydroxylase (CYP24A1), which in turn is highly upregulated by calcitriol itself, as a negative feedback mechanism [1,2].

Importantly, in order for CYP27B1 to fulfill its duty of producing calcitriol, there must be enough substrate available. This requirement is readily accomplished by the endocytic receptors megalin/cubilin and the adaptor protein disabled-2 (Dab2) present in the kidney, where 25OHD in complex with DBP is filtered through the glomerulus and reabsorbed in the proximal tubules by the cooperative action of these proteins [3-5]. Inside the cell, DBP is degraded and 25OHD is released and hydroxylated by CYP27B1. This specialized mechanism allowing renal uptake and activation of 25OHD is paramount for calcitriol production, as demonstrated by Nykjaer A. et al. [3] in rats infused with ${ }^{3} \mathrm{H}-25 \mathrm{OHD} / \mathrm{DBP}$ and where megalin activity was blocked. In these animals, no conversion products (i.e., ${ }^{3} \mathrm{H}$-calcitriol) were recovered from serum samples. In contrast, in animals with intact and active megalin that were also infused, ${ }^{3} \mathrm{H}$-calcitriol was readily detected in their plasma samples. Similarly, the importance of cubilin in the 25OHD reabsorption process is evident in human patients carrying inactivating mutations in cubilin gene (Imerslund-Gräsbeck disease), which exhibit abnormal urinary excretion of 25OHD and DBP [4].

\section{Calcitriol Biological Effects}

Calcitriol actions are mediated through the vitamin D receptor (VDR), a high-affinity ligand-activated transcription factor. Once bound to its ligand, the VDR heterodimerizes with the retinoid X receptor (RXR). This complex recognizes vitamin D response elements (VDRE) in the promoter regions of VD target genes and recruits co-activators or co-repressors in order to induce or repress gene transcription [6]. In addition, non-genomic calcitriol-dependent biological effects can also take place in cells, involving second messengers generated by membrane-initiated signaling pathways [7,8]. Indeed, the classic VDR and the membrane-associated rapid response steroid-binding protein (MARRS) found in the cell membrane may bind calcitriol and initiate the activation of numerous pathways involving protein 
kinase C (PKC) [9], mitogen-activated protein kinase (MAPK) [10], protein kinase A (PKA) [11,12], phosphatidyl inositol phosphate [13] and $\mathrm{Ca}^{2+}$ and chloride channels [8,14]. Very important processes are mediated through these rapid signaling cascades, such as insulin secretion and transcaltachia [15-17]. In general, the known VDRE-containing genes can be grouped in very diverse biological networks including bone and mineral metabolism (i.e., osteopontin [18]); cell life and death (comprising proliferation, differentiation, migration and apoptosis, i.e., p21 [19]), metabolism and cardiovascular health (i.e., cystathionine $\beta$-synthase [20], renin [21] and VEGF [22]), immune function (i.e., cathelicidin hCTD, LL-37 [23,24]) and detoxification (i.e., CYP3A4, CYP24A1 [25]).

\section{Regulation of the VD-Metabolizing Enzymes}

Renal CYP27B1, which is responsible for the most part of circulating calcitriol, is mainly regulated by parathyroid hormone (PTH) -as a signal of calcium status-, fibroblast growth factor 23 (FGF23) -as a signal of serum phosphate levels- and calcitriol itself -as a negative feedback regulatory loop- [26]. When serum calcium levels are low, PTH is secreted by the parathyroid gland in order to stimulate renal CYP27B1 by a cyclic AMP (cAMP)-dependent mechanism [27]. PTH also causes CYP24A1 mRNA degradation in the kidney [28]. Calcitriol production is then boosted, thereby increasing blood calcium levels by promoting absorption of dietary calcium from the gastrointestinal tract, increasing renal tubular calcium reabsorption and stimulating the release of calcium from bone. As feedback effects, the synthesis and secretion of PTH are then inhibited by calcitriol and FGF23, the latter being produced in the bone [29]. FGF23 also potently inhibits CYP27B1 in response to elevated phosphate levels [30]. Finally, calcitriol inhibits its own production by different mechanisms comprising PTH inhibition, direct transcriptional repression of the CYP27B1 gene, and FGF23 and CYP24A1 induction [31]. Other factors that stimulate renal CYP27B1 activity and/or expression are insulin-like growth factor type I (IGF-I) and calcitonin [32-34].

\section{Extra-Renal Regulation of Vitamin D-Hydroxylases}

Extra-renal CYP27B1 is regulated in different ways than those observed in the kidney, in a tissue-specific manner. For instance, macrophage and monocyte CYP27B1 is not stimulated by PTH but rather by cytokines such as interferon- $\gamma$ (INF- $\gamma$ ) and tumor necrosis factor- $\alpha$ (TNF- $\alpha$ ) [35-38]. In addition, CYPB7B1 in immune cells is not readily negatively regulated by calcitriol. Likewise, the negative regulatory loop exerted by CYP24A1 is not very effective; therefore, 25OHD availability is the limiting factor for calcitriol synthesis in these cells [38]. In a similar manner as in immune cells, in keratinocytes, TNF- $\alpha$ and INF- $\gamma$ potently induce CYP27B1 whereas calcitriol does not directly inhibit this gene [39-41]. Nevertheless, CYP24A1 is induced by calcitriol and efficiently degrades bioactive calcitriol, thus regulating calcitriol availability in the epidermis [39]. The transcriptional induction of CYP24A1 by calcitriol is feasible considering the existence of multiple VDREs within its promoter. However, other regulatory mechanisms can also play a role in CYP24A1 regulation, such as alternative splicing, epigenetic gene silencing and metabolism of its mRNA [42-45].

In a comparable fashion as immune cells and keratinocytes, proinflammatory cytokines induce CYP27B1 gene expression in the human placenta [46]. Interestingly, in this tissue, CYP24A1 expression is also stimulated by these factors, suggesting that both synthesis and catabolism of 
placental calcitriol are locally affected by inflammatory cytokines [46]. Nevertheless, we have shown that TNF- $\alpha$ increased significantly the expression of CYP24A1 over CYP27B1, whereas IFN- $\gamma$ preferentially stimulated CYP27B1. These observations, together with those showing that cultured trophoblasts secrete significantly more TNF- $\alpha$ than INF- $\gamma$, suggest that in the placenta, increased TNF- $\alpha$ secretion may limit calcitriol bioavailability [46]. The latter agrees with in vivo evidence showing low serum calcitriol and low placental CYP27B1 expression and calcitriol production in preeclampsia (PE), a pregnancy-associated condition characterized by an exacerbated pro-inflammatory profile.

In contrast to immune and epidermal cells, calcitriol in the placenta is able to transcriptionally inhibit CYP27B1 expression, which is mediated by both the VDR and a cAMP-dependent mechanism [12]. In this tissue, CYP24A1 gene expression is also potently induced by calcitriol [12]. However, it is also recognized that the CYP24A1 gene is methylated in the human placenta, suggesting that epigenetic decoupling of VD feedback catabolism may play an important role in maximizing calcitriol bioavailability at the feto-maternal interface [43]. Nevertheless, as discussed previously by Rosen et al. [47], this assumption is not supported by functional studies, since there is unequivocal evidence for human placental synthesis of 24,25-dihydroxyvitamin $\mathrm{D}_{3}$, the main metabolic product of CYP24A1 [48]. Moreover, in this seminal article by Rubin and colleagues, under physiologic concentrations of $25 \mathrm{OHD}$, placental trophoblasts preferentially synthesize 24,25-dihydroxyvitamin $\mathrm{D}_{3}$ over calcitriol [48], which may explain why fetal levels of 24-hydroxylated VD metabolites are 40-fold higher than calcitriol $[47,49,50]$. These studies strongly suggested that placental CYP24A1 expression and activity, together with substrate availability are important limiting factors for calcitriol synthesis in the feto-maternal interface. Other hormonal factors affecting placental VD-metabolism are IGF-I and the natural occurring calciotropic hormones calcitonin and PTH [12,51]. IGF-I stimulates biotransformation of 25OHD into calcitriol [51], while both calcitonin and PTH regulate the placental VD-hydroxylases in the same manner as calcitriol and cAMP, inducing CYP24A1 while repressing CYP27B1 gene expression, thereby favoring VD catabolism [12].

\section{Physiological Changes of 25OHD, Calcitriol, DBP and VDR during Pregnancy}

During pregnancy, significant changes in maternal serum calcitriol, DBP and placental VDR take place and interact to acquire extra calcium for adequate fetal bone mineralization (for a recent review see Brannon PM and Picciano MF [52]). Indeed, the fetus may accumulate up to $30 \mathrm{~g}$ of calcium at term, and to satisfy this demand, VD metabolism is boosted in order to increase calcium intestinal absorption [53]. Collectively, these changes include increased maternal serum calcitriol, DBP, placental VDR and renal and placental CYP27B1 activity, without changes in serum 25OHD or calcium levels. In fact, maternal ionized calcium does not increase despite higher circulating calcitriol [54-57]; instead, serum calcium remains normal as calcium is transferred to the fetus. This equilibrium could be attributed to the concomitant normal rise in calciuria [55-59], precluding the risk of hypercalcemia. Fetal serum calcium levels are higher than those observed in the mother, a situation that requires specific mechanisms for calcium transport against a concentration gradient. In this regard, the active transplacental passage of calcium to the fetus is mediated by placental expression of calcium binding proteins such as calbindin-D9k and 28k [60-62]. Interestingly, placental VDR has shown to be a positive predictor of fetal femur length and is positively correlated with maternal-to-fetal transfer of 
calcium [63], suggesting that fetal skeletal growth could be affected by VDR-dependent mechanisms; and therefore, the relative VDR placental abundance would be a preponderant feature for fetal bone health.

Maternal 25OHD serum levels remain constant across pregnancy [56,57,59,64], suggesting that the increment observed in serum calcitriol levels is independent of changes in its precursor synthesis. Maternal 25OHD crosses the placental barrier and represents the main pool of VD in the fetus. In fact, serum fetal (cord blood) 25OHD levels are on average 25\% reduced compared to maternal serum and correlate well with mother 25OHD levels [65,66]; therefore, VD deficiency in the mother could be vertically transmitted to the fetus.

During pregnancy, serum calcitriol rises from the first trimester, doubling its concentration compared to non-gravid women by the end of the third trimester and returning to normal values after delivery [54,56,58,59,64,67]. This physiological rise in calcitriol levels observed during pregnancy could be related to increased synthesis rather than decreased clearance [68]. Increased synthesis of calcitriol is linked to higher CYP27B1 activity in maternal kidney, placental trophoblasts and decidua [69-71].

The mechanisms underlying improved CYP27B1 activity during pregnancy remain elusive, partly because its known regulatory factors stay unchanged during this period, such as PTH $[54-56,59]$, which may be even lower with respect to non-gravid women [58,64]. Also, a murine PTH null model supports that PTH does not contribute to increased calcitriol levels during pregnancy [72]. It has been hypothesized [64,73] that a potential regulatory factor for CYP27B1 could be the PTH analog PTH-related peptide (PTH-rP), which is synthesized by fetal parathyroids and placenta [74] and increases throughout pregnancy. PTH-rP could reach the maternal circulation and, after binding to PTH type 1 receptor (PTHR1), it may induce gene expression of CYP27B1 in the kidney and catalyze calcitriol synthesis for endocrine actions. However, this mechanism could not completely explain the higher activity of CYP27B1 in placenta because, as previously described, this tissue has its own mechanisms governing VD metabolism. In fact, PTH downregulates placental CYP27B1 gene expression [12].

The placental contribution to maternal calcitriol levels was demonstrated in 1978 by Weisman and colleagues in a nephrectomized pregnant rat model. In that study, the authors showed that anephric rats can synthesize calcitriol and 24,25-dihydroxyvitamin $\mathrm{D}_{3}$ from 25OHD and that the fetoplacental unit is the most likely site of production of such metabolites [75]. Later, the in vitro synthesis of 24,25-dihydroxyvitamin $\mathrm{D}_{3}$ and calcitriol by the human placenta was demonstrated [69]. Interestingly, in a model of chronic renal failure by Blum and colleagues [76], nephrectomized rats had lower calcitriol levels in comparison with normal rats, but during pregnancy the nephrectomized group reached similar levels to those observed in pregnant controls, despite kidney absence, which emphasized the important contribution of the placenta [76]. In 2000, studies in cultured human placental syncytiotrophoblasts showed that the synthesis of calcitriol from its endogenous precursor was driven by an enzymatic $1 \alpha$-hydroxylation mechanism, since these cells expressed a CYP27B1 gene transcription product with a nucleotide sequence identical to that of transcripts previously characterized in the human kidney [70]. Later, the CYP27B1 protein localization was demonstrated in human placental decidual and trophoblastic cells [77].

In relation to VDR, it has been shown that its gene and protein expression is higher in placental and decidual tissue during the first and second trimesters in comparison with term placentas [78,79], in a 
similar manner as CYP27B1, with highest levels of expression occurring in first trimester decidua [78], thus suggesting a more preponderant role for calcitriol during the first part of pregnancy. It is likely that this is related to the importance of maintaining an anti-inflammatory setting for the acceptance of the fetal allograft. This is discussed further in Section 6.

Regarding DBP, two longitudinal studies indicate that this protein increases $25 \%$ to $56 \%$ during pregnancy [59,67], but the mechanisms leading to this increment are still unknown. It has been hypothesized that the DBP rise may be due to increased calcitriol concentration in gestation. In support of this assumption, serum DBP levels in pregnant women correlated with serum calcitriol levels [80].

The rise in DBP during pregnancy is intriguing and should be taken into consideration for the analysis of VD homeodynamics and physiological impact during this period. Actually, a great debate has been taking place regarding which form of 25OHD is the more suitable for activation, the "free" or the DBP-bound form. In this regard, the "free hormone" hypothesis sustains that the free steroid, by diffusing freely through the cell membrane, is the one available for activation and thereafter capable of performing biological effects, while the hormone bound to its carrier protein is considered to be sequestered and therefore, not bioavailable. However, this hypothesis has been confronted in the last years, given the important transporting and interacting mechanisms existing between the megalin/cubilin complex and DBP/25OHD, together with the observed disparity between the expected amounts of free hormone available for passive diffusion and the levels required to efficiently occupy intracellular target receptors. For an excellent review see: Chun et al. [81]. Interestingly, Chun and colleagues have recently proposed a viable hypothesis considering a role for DBP in tissue discrimination of $25 \mathrm{OHD}_{2}$ and $25 \mathrm{OHD}_{3}$. Given that $25 \mathrm{OHD}_{2}$ binds to $\mathrm{DBP}$ with lower affinity than $25 \mathrm{OHD}_{3}$, the kidney would preferentially use the latter metabolite, while cells in the immune system might profit of a greater pool of $25 \mathrm{OHD}_{2}$ for antimicrobial peptide induction [81].

It is noteworthy mentioning that megalin/cubilin-mediated 25OHD/DBP endocytosis may also take place in the placenta, since these receptors are expressed in this tissue [82-84] and placental calcitriol production has been proved [69,75], suggesting that circulating 25OHD is accessible to placental CYP27B1 by active transport. However, trophoblastic production of calcitriol may also be explained by the steroid freely diffusing through the cell membrane, and consequently both free and bound-25OHD might represent a bioavailable material for placental CYP27B1. Therefore, even if the uptake of $25 \mathrm{OHD}$ by proximal tubule cells evidently depends on the internalization of DBP, the functional significance of the placental megalin/cubilin endocitic complex expression and functionality remains far from clear.

Interestingly, mice with genetic ablation of the DBP gene only presented classic VD-associated problems when maintained under a low VD diet, supporting a role for DBP in maintaining stable serum stores of VD metabolites while modulating the rates of its bioavailability, activation, and end-organ responsiveness [85].

\section{Calcitriol Effects during Pregnancy}

One of the main activities attributed to calcitriol during pregnancy is to increase calcium absorption and to upregulate placental calcium transport. However, since VDR and CYP27B1 are also expressed in reproductive feminine tissues like the uterus, ovary, endometrium, fallopian epithelial cells and 
placenta [86-88], other potential paracrine and autocrine actions of calcitriol cannot be discarded. In this regard, during gestation, VD-dependent regulation of the immune function is paramount, since an adequate balance of the cytokine profile is necessary for pregnancy success. Specifically, calcitriol plays a dual role aimed at improving the innate immune response while restraining exacerbated inflammation. Calcitriol achieves this by inhibiting pro-inflammatory cytokines such as TNF- $\alpha$, IFN- $\gamma$ and interleukin-6 (IL-6), while at the same time induces the potent antimicrobial peptide hCTD in the fetoplacental unit [89-92]. In this tissue, calcitriol also stimulates other antimicrobial peptides known as $\beta$-defensins (HBDs), in particular HBD2 and HBD3 [93].

Calcitriol biological effects in the placenta are also related to hormonogenesis and overall placental physiology. In particular, calcitriol induces endometrial decidualization and estradiol and progesterone synthesis, but also regulates the expression of human chorionic gonadotropin and placental lactogen expression [94-97]. Table 1 lists currently known targets regulated by calcitriol in human placenta.

Considering these important effects of calcitriol on human pregnancy, it is not surprising that VD inadequacy may contribute to many gestation-associated disorders. Herein, we revise some common adverse pregnancy outcomes associated with maternal VD deficiency.

\section{Vitamin D Deficiency and Adverse Pregnancy Outcomes}

As previously mentioned, circulating 25OHD represents the best indicator of VD status. This metabolite was eligible instead of calcitriol for two principal reasons [98]: (1) 25OHD is present in a higher concentration than calcitriol $(\mathrm{ng} / \mathrm{mL} v \mathrm{~s} . \mathrm{pg} / \mathrm{mL})$; and (2) in a deficient 25OHD scenario, PTH is stimulated and consequently induces renal CYP27B1 expression and, therefore, calcitriol synthesis. Consequently, this could derivate in a relative and transient "normality" in calcitriol levels, given its short half-life (few hours for calcitriol instead of 2-3 weeks for 25OHD [99,100]).

The spectrum of VD status has been established considering the known risk for adverse consequences [101]. 25OHD values lesser than $25 \mathrm{nmol} / \mathrm{L}$ are related to rickets and osteomalacia and therefore are labeled as "severe deficiency". 25OHD values lesser than $50 \mathrm{nmol} / \mathrm{L}$ may sustain long-term adverse health consequences and are classified as "deficiency." The $75 \mathrm{nmol} / \mathrm{L}$ cut-off is the point above which there is no upper stimulation of PTH [102] and was thereafter designated as "sufficient." However, Heaney pointed out that 25OHD concentrations $<80 \mathrm{nmol} / \mathrm{L}$ are associated with reduced calcium absorption and osteoporosis risk [103]; therefore, values lesser than $75 \mathrm{nmol} / \mathrm{L}$ are considered as "insufficient." The conversion factor between $25 \mathrm{OHD} \mathrm{nmol} / \mathrm{L}$ and $\mathrm{ng} / \mathrm{mL}$ is 2.5 (Table 2). 
Table 1. Targets modulated by calcitriol in the human placenta ( $+=$ Stimulation; $-=$ Inhibition).

\begin{tabular}{|c|c|c|c|c|c|}
\hline Target & Biological Network & Regulation & Bioeffect & Cell Type & Reference \\
\hline Placental lactogen & Cell life and death & + & Growth control & Trophoblast & [97] \\
\hline \multirow{2}{*}{ TNF- $\alpha$} & \multirow{2}{*}{ Immune function } & - & Restraining inflammation & Trophoblast & {$[91,92]$} \\
\hline & & - & Immunosupression & Decidual cells & [89] \\
\hline \multirow{2}{*}{ IL-6 } & \multirow{2}{*}{ Immune function } & - & Restraining inflammation & Trophoblast & {$[91,92]$} \\
\hline & & - & Immunosupression & Decidual cells & {$[89]$} \\
\hline CSF2 (colony stimulating factor 2) & Immune function & - & Immunosupression & Decidual cells & [89] \\
\hline \multirow{2}{*}{ hCTD } & \multirow{2}{*}{ Immune function } & \multirow{2}{*}{+} & \multirow{2}{*}{ Restraining infection } & Trophoblast & {$[90]$} \\
\hline & & & & Decidual cells & [89] \\
\hline \multirow{2}{*}{ CYP24A1 } & \multirow{2}{*}{ Bone and mineral metabolism } & \multirow{2}{*}{+} & \multirow{2}{*}{ Calcitriol catabolism } & Trophoblast & [12] \\
\hline & & & & Decidual cells & {$[104]$} \\
\hline CYP27B1 & Bone and mineral metabolism & - & Calcitriol synthesis & Trophoblast & {$[12]$} \\
\hline IL-10 (Interleukin 10) & Immune function & - & Reducing risk of infection & Trophoblast & [105] \\
\hline KCNH1 (Potassium voltage-gated channel) & Cell life and death & - & Unknown & Trophoblast & {$[106]$} \\
\hline Calbindin-D 28 kDa & Bone and mineral metabolism & + & Calcium transfer & Trophoblast & {$[61,62]$} \\
\hline Calbindin-D 9 kDa & Bone and mineral metabolism & + & Calcium transfer & Trophoblast & [61] \\
\hline hCG (human chorionic gonadotrophin) & Cell life and death &,+- & Maintenance of pregnancy & Trophoblast & {$[96]$} \\
\hline 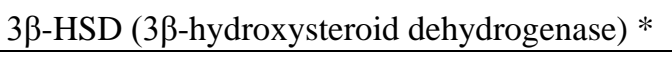 & Cell life and death & + & Progesterone synthesis & Trophoblast & [95] \\
\hline CYP19 (aromatase) * & Cell life and death & + & Estradiol synthesis & Trophoblast & {$[95]$} \\
\hline Prolactin & Cell life and death & + & Establishment of pregnancy & Decidual cells & {$[107]$} \\
\hline VDR & Bone and mineral metabolism & + & Allowing calcitriol actions & Trophoblast & [62] \\
\hline Platelet-activating factor acetylhydrolase & Cell life and death & - & Inactivation of platelet-activating factor & Decidual macrophages & {$[108]$} \\
\hline HOXA10 (Homeobox A10) & Cell life and death & + & Embryo implantation & Decidual cells & {$[109]$} \\
\hline Osteopontin & Bone and mineral metabolism & + & Embryo implantation & Decidual cells & [104] \\
\hline HBD2 & Immune function & + & Restraining infection & Trophoblast & [93] \\
\hline HBD3 & Immune function & + & Restraining infection & Trophoblast & {$[93]$} \\
\hline
\end{tabular}

* Only observed at the enzyme activity level. 
Table 2. Cut-offs in vitamin D status according to the Endocrine Society [110].

\begin{tabular}{ccc}
\hline Vitamin D Status & 25OHD (nmol/L) & 25OHD (ng/mL) \\
\hline Severe deficiency & $<25$ & $<10$ \\
Deficiency & $<50$ & $<20$ \\
Insufficiency & $<75$ & $<30$ \\
Sufficiency & $75-110$ & $30-44$ \\
Toxicity & $>250$ & $>100$ \\
\hline
\end{tabular}

Table 2 shows the criteria for VD status as proposed by the Endocrine Society. We believe this criteria is more applicable to this review since it provides guidance for clinicians caring for patients, as compared to the reference proposed by the Institute of Medicine, more likely intended for normal healthy populations only to ensure skeletal health [111].

Observational studies have described an association between insufficiency or deficiency in 25OHD levels and adverse pregnancy and neonatal outcomes including PE, gestational diabetes, bacterial vaginosis, recurrent abortion, premature rupture of membranes (PROM), preterm delivery, cesarean section, intrauterine growth restriction and also impaired fertility treatment.

The VD literature is growing rapidly and there are some recent and detailed reviews and meta-analyses about adverse pregnancy outcomes and VD [52,112-119]. The purpose of this section is therefore to show a broad overview of VD status and its relationship with epidemiological and observational data in adverse pregnancy outcomes.

\subsection{VD and Preeclampsia (PE)}

$\mathrm{PE}$ is a hypertensive disease associated to gestation. It is clinically diagnosed by new-onset hypertension (140/90 mmHg) and proteinuria (300 mg/24 h or protein dipstick 1+ or greater) after the 20th gestational week $[120,121]$. The major cause related to this disease is abnormal placentation secondary to insufficient throphoblastic invasion that disrupts the endocrine, immunologic and angiogenic environment, resulting in the clinical manifestation of PE [122,123]. Interestingly, a multicenter study with 2030 pregnant women of an American cohort from 1959 to 1966 showed that higher maternal circulating 25OHD levels were associated with a significantly lower risk of placental vascular pathology (hemorrhage, infarcts, microinfarcts, decidual atheromas or thrombosis of cord vessels) in pregnant women carrying male fetuses [124]. From this perspective, VD could be a protective factor for the correct development of placental vasculature.

There is a general consensus in the literature about preeclamptic women having lower 25OHD and calcitriol serum levels compared to normotensive normoevolutive pregnant women [125-129]. Indeed, VD deficiency is more common among preeclamptic women [130-135]. This could partially be explained by significantly lower CYP27B1 placental expression and therefore, lower calcitriol biosynthesis in preeclamptic versus normal placentas [136].

The relationship between VD, especially 25OHD serum levels, and the risk of PE development has been extensively analyzed in the medical literature. Herein, we resume the studies that positively correlate VD deficiency and PE risk (Table 3). 
Table 3. Observational studies on 25OHD serum levels and the risk for PE development.

\begin{tabular}{|c|c|c|c|c|}
\hline Reference & $\begin{array}{c}\text { Sample Size } \\
\text { (PE Cases vs. Controls) }\end{array}$ & $\begin{array}{l}\text { Weeks of Gestation for } \\
\text { Blood Sampling }\end{array}$ & 250HD Cut off & $\begin{array}{c}\text { Risk for PE Development } \\
\text { (OR (95\% CI)) }\end{array}$ \\
\hline \multirow{2}{*}{ [130] } & \multirow{2}{*}{$100 \mathrm{PE}$ and 100 controls } & \multirow{2}{*}{$>24$} & $<75 \mathrm{nmol} / \mathrm{L}$ & $3.26(1.12-9.54)$ \\
\hline & & & $<37.5 \mathrm{nmol} / \mathrm{L}$ & $4.23(1.4-12.8)$ \\
\hline \multirow[b]{2}{*}{ [131] } & \multirow[b]{2}{*}{$\begin{array}{c}33 \mathrm{PE}, 79 \text { eclamptic } \\
\text { and } 76 \text { control }\end{array}$} & \multirow[b]{2}{*}{$\begin{array}{l}\geq 20 \text { weeks, prior to } \\
\text { magnesium sulfate therapy }\end{array}$} & \multirow[b]{2}{*}{$<5 \mathrm{nmol} / \mathrm{L}$} & $3.9(1.18-12.87)$ for $\mathrm{PE}$ \\
\hline & & & & $\begin{array}{c}5.14 \text { (1.98-13.37) } \\
\text { for eclampsia }\end{array}$ \\
\hline$[132]$ & $32 \mathrm{PE}$ and 665 controls & $24-26$ & $<50 \mathrm{nmol} / \mathrm{L}$ & $3.24(1.37-7.69)$ \\
\hline$[133]$ & $\begin{array}{c}51 \text { severe PE } \\
\text { and } 204 \text { controls }\end{array}$ & $15-20$ & $<50 \mathrm{nmol} / \mathrm{L}$ & $3.63(1.52-8.65)$ \\
\hline [134] & 55 PE and 219 controls & 22 & $<37.5 \mathrm{nmol} / \mathrm{L}$ & $5.0(1.7-14.1)$ \\
\hline
\end{tabular}

$\mathrm{PE}=$ Preeclampsia; $\mathrm{OR}=$ odds ratio; $\mathrm{CI}=$ confidence interval.

Interestingly, Robinson and colleagues [129] found that a $10 \mathrm{ng} / \mathrm{mL}$ increase in $25 \mathrm{OHD}$ levels yields a $63 \%$ decrease in the risk of severe PE, strongly suggesting that pregnant women should have VD sufficiency in order to lower the risk for PE development. In support of this postulation, recently, Bodnar and coworkers [137] studied a large cohort with 717 PE women and 2,986 control women, concluding that maternal VD deficiency is a clear risk factor for severe PE development. Specifically, they found that maternal $25 \mathrm{OHD}$ levels $\geq 50 \mathrm{nmol} / \mathrm{L}$ reduce in $40 \%$ the risk of severe PE development in comparison to women with $25 \mathrm{OHD}<30 \mathrm{nmol} / \mathrm{L}$. Another study reports that both $25 \mathrm{OHD}$ and soluble VEGF receptor type 1/placental growth factor (sFlt-1/PIGF) ratio at 15-20 weeks of gestation were significant predictors of severe PE [138]. Similarly, a Norwegian study [139] revealed that increased VD intake (15-20 $\mu \mathrm{g}$ /day) decreases about $25 \%$ the risk for PE development, and four independent meta-analyses showed a significant association between PE and 25OHD insufficiency or deficiency compared with control groups [112,119,140,141].

Despite all these reports, other authors inform they did not find any relation between maternal 25OHD levels and risk of PE development [142,143].

In summary, this data supports that maintaining VD sufficiency is a relatively simple measure (by cholecalciferol supplementation or reasonable skin sun exposure) for preventing one of the major causes in mother and baby morbidity-mortality, namely, preeclampsia.

\subsection{VD and Bacterial Vaginosis}

Bacterial vaginosis (BV) is a common infectious disease in reproductive-aged women. It is caused by the replacement of normal vaginal flora (especially Lactobacillus) for mixed anaerobic bacteria [144]. Its importance during pregnancy resides in the association of BV with adverse gynecologic and obstetric outcomes such as PROM, which can cause spontaneous or induced preterm delivery [145].

Interestingly, the National Health and Nutrition Examination Survey (NHANES) 2001-2004 reported that black women suffer two-fold more BV cases in comparison to white women (51.6\% vs. $23.2 \%$, respectively) [146]. This proportion could be explained by the fact that high melanin levels in darkly pigmented skin blocks ultraviolet radiation reducing cutaneous VD photosynthesis and consequently, decreasing the well-known antimicrobial activity of endogenous calcitriol $[147,148]$. 
Observational studies support this hypothesis. A prospective cohort study [149] developed at Pittsburgh University followed 469 pregnant women from <16th gestational week to term. It was observed that mothers with $25 \mathrm{OHD}$ serum levels $<20 \mathrm{nmol} / \mathrm{L}$ had a $65 \%$ increased risk of developing BV compared to $25 \mathrm{OHD}$ sufficient women (>80 nmol/L), and similarly, in a subsample of the Nashville Birth Cohort [150], 25OHD serum levels were lower in women who developed BV during pregnancy. In a secondary analysis of data from the NHANES 2001-2004, Hensel and coworkers [151] described that VD insufficiency or deficiency had a statistically significant association with BV only among pregnant women (adjusted OR 2.87, 95\% CI 1.13-7.28). Interestingly, a meta-analysis comprising 16 independent studies showed that women with bacterial or viral infections presented 2.1 increased risk (95\% CI: 1.6-2.7) of PE development [152], suggesting a probable common risk factor which could be VD deficiency.

Besides BV, calcitriol can prevent other kinds of infections during pregnancy. In human bladder biopsies and established bladder cell lines, 25OHD treatment induced hCTD gene expression, which diminished uropathogenic E. coli infection, suggesting that adequate 25OHD serum levels could help prevent urinary tract infections [153].

In addition, a case-control study [154] reports that pregnant women with 25OHD insufficiency at 14-16 gestational week had 2.1-fold increased risk in developing severe to moderate periodontal disease (95\% CI: 0.99-4.5).

The physiological mechanisms underlying these observations are possibly related to immune responses regulated by calcitriol. In fact, as previously mentioned, calcitriol can induce innate immune responses by activating hCTD in placenta, macrophages and dendritic cells [90,155]. The antimicrobial hCTD is an active peptide with broad spectrum antimicrobial activity (anti-Gram-positive and Gram-negative bacteria, mycobacterias, spirochetas and yeasts). Its mechanism of action includes bacterial membrane disruption and activation of toll-like receptors and macrophage and neutrophil chemotaxis [156]. Recently, it was also found that calcitriol can induce hCTD expression, multivesicular endosomes and phagolysosome biogenesis in macrophages, leading to microbial killing through autophagy [157-159]. Other important antimicrobial peptides induced by calcitriol in the placenta are HBD2 and HBD3, which also play a shielding role upon infections. Conjointly, these endogenous antibiotics provide an efficient mechanism of front-line defense since they have the capacity to kill a wide variety of microorganisms throughout the female reproductive tract [160]. Interestingly, it has been shown that IL-10, a physiological suppressor of maternal active immunity, downregulates placental antimicrobial peptides expression, which may be permissive for microbial invasion, since the placenta represents a mechanical and immunological barrier essential to restrict infection progress. However, calcitriol is able to antagonize IL-10 suppressive effects upon placental innate defenses by downregulating IL-10 expression, while at the same time restraining exacerbated inflammation and subsequently helping pregnancy to continue in quiescence $[93,105]$. These data indicate that adequate VD levels are crucial to enhance immunity.

By reducing infections, calcitriol may exert protective effects upon PROM. However, another mechanism might be involved in PROM prevention: calcitriol, either alone or combined with lipopolysaccharide endotoxin, decreases oxitocin and connexin 43 expression in myometrial smooth muscle cells, both proteins are associated with uterine contractions [161]. These results suggest that calcitriol can modulate uterine quiescence even under bacterial infection and therefore can prevent the 
abnormal uterine contractions that favor PROM and preterm delivery. In this sense, 25OHD could exert a protective role in preterm birth but this still remains unclear, since in a multicenter American cohort with twin-gestation women [162], it was observed that women with sufficiency in $25 \mathrm{OHD}(>75 \mathrm{nmol} / \mathrm{L}$ ) had a $60 \%$ lower risk of preterm labor in comparison to those $<75 \mathrm{nmol} / \mathrm{L}$ (OR 0.4, 95\% CI 0.2-0.8). However, in a case-control study with women at high risk for prior preterm birth, VD status at 16-22 gestational weeks was not associated with recurrent preterm birth [163].

\subsection{Vitamin D and Gestational Diabetes}

Gestational diabetes mellitus (GDM) is defined as carbohydrate intolerance resulting in hyperglycemia of variable severity with new-onset or first recognition during pregnancy $[164,165]$. GDM, one of the most common complications of pregnancy, is related to adverse outcomes that increase morbidity and mortality in mothers and neonates, including hypertension, PE, urinary tract infection, caesarean delivery, fetal macrosomia, neonatal hypoglycemia and high long-term risk for metabolic syndrome or diabetes mellitus type 2 (DM2) development [165-167].

The classic risk factors known for GDM include maternal overweight status or obesity, prior history of GDM, family history of DM2, antecedent of macrosomic infant, and increased maternal age [165]. However, since 1980 [168], there is a constantly growing body of evidence that supports a connection between VD and insulin or glucose metabolism.

Some observational studies reported lower 25OHD levels in pregnant women with GDM in comparison with normal pregnant women [169-176]. In Table 4, studies that evaluated serum 25OHD levels and the risk for GDM are shown.

Table 4. Observational studies on 25OHD serum levels and risk for GDM development.

\begin{tabular}{ccccc}
\hline Reference & $\begin{array}{c}\text { Sample Size } \\
\text { (GDM Cases vs. Controls) }\end{array}$ & $\begin{array}{c}\text { Weeks of Gestation for } \\
\text { Blood Sampling }\end{array}$ & $\begin{array}{c}\text { 25OHD } \\
\text { Cut off }\end{array}$ & $\begin{array}{c}\text { Risk for GDM Development } \\
\text { (OR (95\% CI)) }\end{array}$ \\
\hline$[169]$ & 20 GDM and 40 controls & At delivery & $<50 \mathrm{nmol} / \mathrm{L}$ & $30.78(4.65-203.90)$ \\
\hline$[177]$ & $\begin{array}{c}\text { 68 GDM and 1,246 } \\
\text { controls }\end{array}$ & $26-28$ & $<25 \mathrm{nmol} / \mathrm{L}$ & $3.6(1.7-7.8)$ \\
\hline$[171]$ & $116 \mathrm{GDM}$ and 219 controls & $15-18$ & $<73.5 \mathrm{nmol} / \mathrm{L}$ & $2.21(1.19-4.13)$ \\
\hline$[178]$ & $200 \mathrm{GDM}$ and 200 controls & $26-28$ & $<25 \mathrm{nmol} / \mathrm{L}$ & $1.80(1.209-2.678)$ \\
\hline$[172]$ & 54 GDM and 111 controls & $24-28$ & $<37.5 \mathrm{nmol} / \mathrm{L}$ & $2.66(1.26-5.6)$ \\
\hline$[173]$ & 57 GDM and 114 controls & 16 & $<50 \mathrm{nmol} / \mathrm{L}$ & $2.02(0.88-4.6)$ \\
\hline$[170]$ & 81 GDM and 226 controls & Between 2nd and 3rd trimester & $<50 \mathrm{nmol} / \mathrm{L}$ & $1.92(0.89-4.17)$ \\
\hline
\end{tabular}

GDM = Gestational diabetes mellitus; OR = odds ratio; $\mathrm{CI}$ = confidence interval.

In a meta-analysis made by Poel and coworkers [179], the mean odds ratio calculated for GDM from 7 independent observational studies about 25OHD deficiency was 1.61 (95\% CI 1.19-2.17). Similarly, a review on VD status and GDM risk concluded that maternal VD deficiency and insufficiency are associated with markers of altered glucose homeostasis [180].

Other studies correlated serum 25OHD levels with a significant inverse association with glucose metabolic response in women with GDM: higher serum 25OHD was found to be associated with at 
least one of the following parameters: lower fasting glucose, lower $2 \mathrm{~h}$ glucose (post oral glucose tolerance test), lower glycosylated hemoglobin, lower serum insulin, lower insulin resistance or lower homeostasis model of assessment of insulin resistance HOMA-IR [170,171,174,175,178,181-184].

In the future, the VD and lifestyle intervention (DALI) protocol could provide interesting information about VD supplementation and GDM risk. DALI is a multicenter European protocol in which the risk of GDM is being evaluated in 880 pregnant women divided into eight intervention groups considering physical activity, healthy eating habits and VD 3 supplementation (1600 IU/day or placebo). Unfortunately, the results from this study are still unpublished [185]. To our knowledge, there is only one published double-blind randomized controlled clinical trial which supplemented VD3 on pregnant women with GDM [186]. In this study, pregnant women received two oral doses of 50,000 IU (baseline and day 21) or placebo capsules after 24 weeks of gestation. Women treated with VD 3 had a significant increase in 25OHD serum levels and a significant decrease in fasting glucose, insulin serum and HOMA-IR, which supports positive glucose metabolic effects on mothers by $\mathrm{VD}_{3}$ supplementation. Similarly, Mozzafari and coworkers [187] administered a single intramuscular $\mathrm{VD}_{3}$ dose (300,000 IU) post-partum in 45 women with GDM. After three months of intervention, treated women presented significantly higher 25OHD levels and lower HOMA-IR than women with GDM in the control group.

Contradictorily to this background, there are some studies which concluded that there are no significant differences between VD status in women with GDM or controls [182,188,189], or conclude that VD deficiency is not a risk factor for GDM [190,191].

There is little consensus about the physiological mechanisms governing calcitriol and glucose metabolism connections. The classic mechanism known is that calcitriol can regulate intracellular calcium flux on $\beta$-pancreatic cells and therefore can modulate depolarization-stimulated insulin release [17]. However, there are recent evidences that include other VD-dependent mechanisms: (a) diminished inflammatory state in obesity and enhanced expression of genes involved in glucose and lipid metabolism like peroxisome proliferator-activated receptor gamma (PPAR $\gamma$ ) or its coactivator (PGC1 $\alpha$ ) in peripheral blood mononuclear cells [192]; (b) weight reduction and muscle insulin receptor substrate 1 (IRS-1) upregulation [193]; (c) upregulation of adipocyte glucose transporter 4 (GLUT4) protein and its translocation to the cell surface [194]; and d) returning to normal liver activity of glucose metabolic enzymes hexokinase, fructose 1,6-bisphosphatase and glucose 6-phosphatase [195]. In GDM, these VD-modulated beneficial mechanisms could be altered, at least in part, because placentas from GDM mothers have higher CYP24A1 protein and gene expression which can derivate in lower calcitriol bioavailability [169].

\subsection{Vitamin D and Low Birth Weight or Small for Gestational Age}

Newborns small for gestational age (SGA) are defined as those with a birth weight for gestational age below to the 10th percentile in standard growth curves ( $<5$ th and 3rd percentiles are also used), whereas low birth weight is defined as newborn weight lower than $2500 \mathrm{~g}$ independently of gestational age [196,197]. These complications are associated with substantially higher rates of perinatal morbidity and mortality, including cerebral palsy, neonatal polycythemia, hyperbilirubinemia, and hypoglycemia [197]. 
The associations between serum maternal 25OHD levels and birth weight of SGA newborns have not been extensively studied. Epidemiological analyses support that black infants had lower birth weight than white infants, which suggests a possible role of VD [198]. However, there are still controversial opinions about lower VD levels failing to modulate fetal growth or if external parameters as maternal obesity, lower socioeconomic status or poor nutrition contribute to lower 25OHD levels and also to SGA and low birth weight development [199]. Herein, we present the major findings in this area. Few studies did not find a significant relation between birth weight for SGA proportion and 25OHD levels [190,200-202]; however, many observational studies did. A multicenter cohort study indicated that maternal $25 \mathrm{OHD}$ levels $>37.5 \mathrm{nmol} / \mathrm{L}$ are associated with higher birth weight infants in comparison to newborns from women with lesser than $37.5 \mathrm{nmol} / \mathrm{L}$ [203]. Another study indicates that pregnant women who delivered SGA infants had lower serum 25OHD levels at 11-13 gestational weeks [204]. Also, umbilical cord serum calcitriol concentrations were lower in SGA than in adequate weight for gestational age infants [205]. In this study, maternal 25OHD levels were also lower in the SGA group but did not reach statistical significance. Similarly, in a birth cohort study, women with 25OHD levels between 8.5 and $48 \mathrm{nmol} / \mathrm{L}$ were more likely to give birth to SGA offspring (OR 1.57, 95\% CI 1.03-2.39) [206].

Dietary analysis of total $\mathrm{VD}_{3}$ intake was a significant predictor of infant birth weight adjusted for gestation [207], whereas milk or VD intake during pregnancy were significant independent predictors of birth weight [208]. However, it seems that placental weight is not related to 25OHD levels [203].

In a case-control study, Bodnar and colleagues [209] also observed that pregnant women with $250 H D$ deficiency ( $<37.5 \mathrm{nmol} / \mathrm{L}$ ) had an increased significant risk of SGA development in offspring. Interestingly, this effect was more evident in white women (OR 7.5, 95\% CI 1.8-31.9) in comparison to black women (OR 1.5, 95\% CI 0.6-3.5). Unexpectedly, the women with 25OHD insufficiency (37.5-75 nmol/L) presented a lower risk of SGA than women with $25 \mathrm{OHD}$ sufficiency $(>75 \mathrm{nmol} / \mathrm{L}$ ) in both black and white women. The authors discuss that the potential mechanisms which can explain this U-shaped SGA risk remain uncertain, but the risk of other diseases such as allergic responses or atopic disorders present a similar pattern.

We only found one interventional study about VD and birth weight. In a partially randomized assay on pregnant women, the intervention with one single oral dose of $1500 \mu \mathrm{g} \mathrm{VD}_{3}$ (equal to 60,000 IU) or two doses of $3000 \mu \mathrm{g}$ each (equal to 120,000 IU) in the 2nd and 3rd trimesters resulted in higher birth weight and length in comparison to newborns of mothers treated with usual care [210].

Interestingly, interventional studies with calcium and VD3 performed in pregnant adolescents showed that both nutrients positively influenced fetal bone growth in utero, and that even if both factors were needed for fetal bone health, one could partially compensate for the other [211]. This study suggests that special attention should be paid to pregnant adolescents in order to fulfill adequate VD and calcium requirements, since not only fetal but also maternal bone health may be at risk. This is supported by other studies showing that lactating adolescents lose more bone mineral density when suffering from VD deficiency or low calcium intake [212].

Interestingly, Morley and colleagues suggested that studies on maternal VD status and birth weight should consider neonatal VDR polymorphism, since differences in this feature could help explain why findings from different populations regarding maternal VD status and neonate birth weight have been inconsistent [213]. 


\section{Vitamin D Expenditure and Homeodynamics: Considerations for VD Supplementation}

\subsection{Endogenous and Exogenous Factors Affecting the VD Status Equation}

Considering the high risk of adverse events during pregnancy associated to VD deficiency, it is also important to analyze additional factors that may significantly modify the bioavailability of VD and its metabolites in our body. Indeed, the VD endocrine system is not in constant equilibrium; instead, it is under dynamic regulation and interaction with different factors. For example, the half-life of 25OHD is strongly influenced by DBP concentration, since 25OHD binds to DBP with high affinity [81,214]. Moreover, 25OHD is also affected by DBP genotype [214]. Indeed, the genetic variations that occur in DBP modify its binding affinity for VD metabolites, and the lesser affinity, a shorter half-life is expected. Similarly, genetic variations in CYP27B1, CYP24A1, CYP2R1 and the VDR differentially impact on VD metabolism and biological effects. Single nucleotide polymorphisms have been reported for each of these proteins and may be found as population-specific variants that result in modification of the final VD status. For reviews on this issue please see [215-217]. Considering this, and as previously suggested [215], it is feasible that optimal concentrations of 25OHD required to reduce disease outcomes may vary according to genotype. Other endogenous elements that may predict serum 25OHD half-life are factors known to affect 25OHD metabolism, such as PTH, plasma phosphate and albumin-adjusted calcium [218].

Besides the endogenous factors previously described, exogenous aspects affecting 25OHD plasma concentration include dietary intake, type of clothing and sunshine protection [219], lifestyle and geophysical conditions, this last one interpreted as UVB exposure. In this regard, a study performed with pregnant women in Germany showed that during the winter months, 98\% of the maternal blood samples and $94 \%$ of the cord blood samples had $250 \mathrm{HD}$ levels $<50 \mathrm{nmol} / \mathrm{L}$, while in the summer months, only $49 \%$ of the women and $35 \%$ of the cord blood samples were vitamin D deficient [220]. Interestingly, in the same study, the authors found that a significant risk factor for maternal VD deficiency was physical inactivity (adjusted OR 2.67, 95\% CI 1.06-6.69, $p=0.032$ ), which might be related to less sun exposure. However, a sedentary lifestyle may also be associated with obesity, which has been found to be linked to VD deficiency. Indeed, obese subjects normally have lower basal 25OHD serum concentrations than lean individuals [221], which is possibly explained by the fact that VD is readily stored in adipose tissue due to its fat-soluble nature. In this manner, VD may be sequestered in the greater body pool of fat present in obese individuals, which is supported by previous studies showing that after equal whole-body irradiation or VD supplementation, the increase in serum VD was more than 50\% lower in obese than in non-obese subjects [221]. While this occurs in body fat, the muscle cells protect 25OHD from degradation by binding it to actin fibers, in a megalin-dependent process [222]. This may explain why 25OHD concentrations are usually positively associated to muscle-related parameters such as lean body mass and exercise [223].

Unfortunately, during pregnancy, the toll of VD deficiency in obese mothers affects also their child's VD status and health [224,225]. Many studies have shown an array of adverse health outcomes in the offspring of obese women; for example, lower maternal VD status may be linked to programmed differences in offspring fat mass [224,226]. Among the more important adverse effects of maternal VD deficiency upon their offspring, impaired fetal growth and bone development, altered growth and bone 
mass later in childhood, neonatal hypocalcemia or tetany and respiratory tract infections have been reported [227].

\subsection{Dose Regimens and Vitamin D Supplementation in Pregnant Women}

Despite the health advantages associated with a sufficient VD status during pregnancy, as described previously, at this time general consensus supporting a guideline for VD supplementation in pregnant population has not yet been reached. In the literature, a broad spectrum for dosage and periodicity in cholecalciferol supplementation schemes has been reported: 2000 IU, 4000 IU, 14,000 IU, 60,000 IU, 120,000 IU or 200,000 IU administered daily, weekly, monthly or in a single mega-dose. Herein, we resume the more recent randomized clinical trials on VD supplementation in pregnancy. Table 5 includes doses and frequency for supplementation together with the outcome as percentage of women who achieved VD sufficiency at the end of intervention and those who developed hypercalcemia.

Based on these data, it seems that 4000 IU given daily results in the highest proportion of pregnant women reaching VD sufficiency without developing hypercalcemia. An exception to this observation is the study by Hossain et al. [228], in which only 15\% women reached sufficiency under this regimen. Regarding this, we should mention that the group of Pakistani women included in the Hossain study were severely VD deficient $(<25 \mathrm{nmol} / \mathrm{L})$ and were an ethnic group in which particular genetic variants might be affecting VD metabolism, which remains to be further studied. Moreover, the cases of hypercalcemia were comparable in both control and supplemented groups, while hypercalcemia persisted despite VD deficiency, suggesting independence of the pharmacological intervention. On the other hand, it should be noted that in the study by Wagner et al. [229], the percentage of women considered to attain sufficiency might be underestimated, since their cut-off value was 25OHD serum levels $>100 \mathrm{nmol} / \mathrm{L}$. As in the case of $4000 \mathrm{IU}$ given daily, the weekly regimen of 50,000 IU seems to be also a good therapeutic strategy, since $100 \%$ women reached sufficiency without hypercalcemia. However, more studies are needed to confirm these findings.

In contrast, monthly and unique dose regimens do not seem to adequately fulfill VD sufficiency. It is noteworthy that under the single-dose regimen, some authors included in their analyses serum levels below $75 \mathrm{nmol} / \mathrm{L}$ (identified with * and ** in Table 5), which under the Endocrine Society parameters is still considered deficiency. Indeed, in the study by Sahu et al. [230], which considered a cut-off of $75 \mathrm{nmol} / \mathrm{L}$, only $34.2 \%$ of women reached sufficiency with the highest dose, which is very low. Similarly, in the study by Yu et al. [231], the observed proportion of 93\% in the supplemented group might be misleading, since this number includes women with serum $250 H D$ levels $>25 \mathrm{nmol} / \mathrm{L}$.

The recent evidence discussed in Section 8.1 may help us to understand the differences in VD expenditure and homeodynamics in order to reach a general consensus on VD supplementation in a tailored manner. We believe, that at this moment, the ideal scheme for VD supplementation will depend on particular endogenous and exogenous factors, on the available formulations of VD (i.e., in Mexico only tablets with 400 IU are available), and on the personal VD metabolism, which should be monitored periodically by serum 25OHD analyses. By taking all these considerations into account, and under medical counseling and supervision, every woman may modulate their VD levels for acquiring sufficiency and avoiding possible toxicity that could lead to hypercalcemia. 
Table 5. Cholecalciferol supplementation and VD status in randomized clinical trials in healthy pregnant women.

\begin{tabular}{|c|c|c|c|c|c|}
\hline Reference & Sample Size & Period of Supplementation & Cholecalciferol Supplemented (IU) & $\begin{array}{c}\text { \% Women with Serum } 250 H D>75 \mathrm{nmol} / \mathrm{L} \\
\text { at Delivery (No Asterisk) }\end{array}$ & Hypercalcemia \\
\hline \multicolumn{6}{|c|}{ Unique Dose } \\
\hline \multirow{2}{*}[210]{} & \multirow{2}{*}{97} & 2nd trimester & 60,000 & $27 \% * *$ & \multirow{2}{*}{ No evaluated } \\
\hline & & Two doses at 2nd and 3rd trimester & 120,000 & $62.5 \% * *$ & \\
\hline \multirow{3}{*}[230]{} & \multirow{3}{*}{84} & No supplementation & - & $7 \%$ & \multirow{3}{*}{ No evaluated } \\
\hline & & 5th month & 60,000 & $5.7 \%$ & \\
\hline & & Two doses at 5th and 7th month & 120,000 & $34.2 \%$ & \\
\hline \multirow{2}{*}[231]{} & \multirow{2}{*}{180} & No supplementation & - & $60 \% *$ & \multirow{2}{*}{ No indicated } \\
\hline & & 27 week & 200,000 & $93 \% *$ & \\
\hline \multicolumn{6}{|c|}{ Daily } \\
\hline \multirow{3}{*}[232]{} & \multirow{3}{*}{228} & \multirow{3}{*}{27 weeks to term } & 0 & $50 \%$ & \multirow{3}{*}{ No } \\
\hline & & & 1000 & $89 \%$ & \\
\hline & & & 2000 & $91 \%$ & \\
\hline \multirow{2}{*}{ [228] } & \multirow{2}{*}{175} & \multirow{2}{*}{ Less than 20 weeks to term } & 0 & $1 \%$ & 3 cases \\
\hline & & & 4000 & $15 \%$ & 9 cases \\
\hline \multirow{3}{*}[233]{} & \multirow{3}{*}{162 deficient women } & \multirow{3}{*}{$12-16$ weeks to term } & 400 & $9.5 \%$ & \multirow{3}{*}{ No } \\
\hline & & & 2000 & $24.4 \%$ & \\
\hline & & & 4000 & $65.1 \%$ & \\
\hline \multirow{2}{*}{ [229] } & \multirow{2}{*}{257} & \multirow{2}{*}{$12-16$ weeks to term } & 2000 & $37.4 \% * * *$ & \multirow{2}{*}{ No } \\
\hline & & & 4000 & $46.2 \% * * *$ & \\
\hline \multirow{3}{*}[234]{} & \multirow{3}{*}{350} & \multirow{3}{*}{$12-16$ weeks to term } & 400 & $50 \%$ & \multirow{3}{*}{ No } \\
\hline & & & 2000 & $70.8 \%$ & \\
\hline & & & 4000 & $82 \%$ & \\
\hline$[231]$ & 180 & 27 weeks to term & 800 & $86 \% *$ & No indicated \\
\hline
\end{tabular}


Table 5. Cont.

\begin{tabular}{|c|c|c|c|c|c|}
\hline Reference & Sample Size & Period of Supplementation & Cholecalciferol Supplemented (IU) & $\begin{array}{c}\text { \% Women with Serum } 25 \mathrm{OHD}>75 \mathrm{nmol} / \mathrm{L} \\
\text { at Delivery (No Asterisk) }\end{array}$ & Hypercalcemia \\
\hline \multicolumn{6}{|c|}{ Weekly } \\
\hline \multirow{2}{*}{ [235] } & \multirow{2}{*}{109 deficient women } & \multirow{2}{*}{ 26-28 weeks to term (8 weeks) } & 400 & $3.70 \%$ & \multirow{2}{*}{ No } \\
\hline & & & 50,000 & $100 \%$ & \\
\hline \multirow{2}{*}{ [236] } & \multirow{2}{*}{28} & \multirow{2}{*}{ 26-28 weeks to term } & Basement 70,000 + 35,000 weekly & $90 \%$ & \multirow{2}{*}{ No } \\
\hline & & & 14,000 weekly & $56 \%$ & \\
\hline \multicolumn{6}{|c|}{ Monthly } \\
\hline \multirow{2}{*}{ [237] } & \multirow{2}{*}{51 deficient women } & \multirow{2}{*}{ From 2nd month to term } & 50,000 & $35 \% * * * *$ & \multirow{2}{*}{ No evaluated } \\
\hline & & & 100,000 & $59 \% * * * *$ & \\
\hline
\end{tabular}

* 25OHD serum > $25 \mathrm{nmol} / \mathrm{L}$; ** 25OHD serum $>50 \mathrm{nmol} / \mathrm{L} ; * * * 25 \mathrm{OHD}$ serum $>100 \mathrm{nmol} / \mathrm{L} ; * * * *$ in cord blood. 


\section{Methods of Serum VD Measurement}

Since four decades ago, numerous analytical methods have been developed for 25OHD measurement, including competitive protein binding assay, enzyme-linked immunoassay (ELISA), radioimmunoassay (RIA), chemiluminescence assay, gas chromatography-mass spectrometry (GC-MS), high performance liquid chromatography (HPLC) and, more recently, liquid chromatography coupled with mass spectrometry (LC-MS) or tandem mass spectrometry (LC-MS/MS). A good review of accuracy, sensibility and technical description of these methods was made by Hollis [238].

LC-MS/MS is the most promising technique for VD analysis since it is a highly specific, reliable, reproducible and robust method and is considered the new gold standard for 25OHD quantification [239,240]. Despite its major field of application being research, LC-MS/MS technology is also currently being applied in clinical laboratories [241]. In addition, LC-MS/MS offers the possibility for quantifying other metabolites of VD in serum samples, such as $25 \mathrm{OHD}_{2}, 25 \mathrm{OHD}_{3}$, 3-epi-25OHD2, 3-epi-25OHD, 24R, 25 dihydroxyvitamin $\mathrm{D}_{3}$ [242,243] and 25OHD 3 3-sulfate [244]. Other metabolites as $\mathrm{VD}_{2}, \mathrm{VD}_{3}, 1 \alpha, 25(\mathrm{OH})_{2} \mathrm{D}_{2}$ and $1 \alpha, 25(\mathrm{OH})_{2} \mathrm{D}_{3}$ may also be detected and discriminated.

One limitation of this technique is the interference with 3-epi $25(\mathrm{OH}) \mathrm{D}_{3}$ that can lead to $25 \mathrm{OHD}$ overestimation. This could be a problem especially in pediatric samples which are known to have significant amounts of this epimer. Recently, van den Ouweland and colleagues developed a LC-MS/MS method which eliminates this limitation [245].

Interestingly, new technology developed to be used in our daily life will allow us to measure 25OHD easily at home. The proposed system is a gold-nanoparticle-immunoassay developed at Cornell University, adapted to a device that couples to smartphones allowing them to calculate in a small drop of blood 25OHD serum concentrations with $10 \mathrm{nM}$ sensitivity [246].

In the aftermath of what is discussed in Sections 5 and 8.1, it seems that 25OHD should not be exclusively considered for the assessment of VD, but rather, the equation for VD status may also consider DBP levels. Powe and coworkers [247] recently suggested that free 25OHD (25OHD minus DBP) is a better indicator for VD status since free 25OHD offers a strong correlation with PTH than total 25OHD. However, this article has been criticized by other authors [248]. Indeed, as previously discussed, Weintraub [248] pointed out that the 25OHD/DBP complex is necessary for the endocytosis by megalin/cubilin in the kidney, so $25 \mathrm{OHD}$ bound to DBP may be the real substrate mediating final calcitriol biosynthesis. Nevertheless, this would only apply to those cells expressing megalin/cubilin, and definitive further studies are needed in order to clarify the participation of other mechanisms of 25OHD storage and internalization into the cell.

\section{Final Considerations}

Maintaining adequate VD serum concentrations within the recommended levels is mandatory during pregnancy, since it is involved in many important biological processes, including fetal programming and development. Indeed, the benefits of maintaining adequate VD serum levels are not circumscribed to the mother, but also to the offspring. It is noteworthy mentioning that epidemiological studies have shown controversial results about the benefits of prescribing VD supplements to prevent adverse pregnancy outcomes associated with maternal deficiency. We believe 
that the controversy may be explained because the biological phenomena can be affected not only by serum concentrations, but also by many factors, such as racial, climatological, or genetic reasons; nutritional status; lifestyle; physical activity; or health status during pregnancy. On the other hand, the few studies that do not corroborate benefits lack sustained clinical evidence of real risks due to VD supplementation. Conversely, systematic reviews and meta-analyses demonstrate a strong association between VD adequate levels and health benefits. Regarding this controversy, recently, two debated articles concluded that the proposed adverse health outcomes related to VD deficiency might be, in fact, the result of reverse causation, understanding by this that low VD levels are a consequence of ill health rather than a cause, and that the evidence does not really support VD supplementation for prevention of disease [249-251]. In response to these articles, Gillie, with straightforward arguments, demonstrated that the aforementioned articles had made a type 2 statistical error, and that VD deficiency, especially at critical times such as pregnancy and early childhood, could derive in serious health harm [252]. An example of the arguments exposed by Gillie is rickets, a disease characterized by bone deformation in children caused by VD deficiency. This illness may be corrected by adequate VD supplementation during childhood, but the alterations in bones cannot be reversed by this intervention once adulthood is reached. Another example discussed by Gillie is diabetes type 1, which occurs in children and is thought to be caused by VD deficiency in the womb, causing irreversible changes to biochemistry, immune status or organ structure.

A final consideration is the fact that VD supplementation is useful to prevent adverse pregnancy outcomes, but it might not always be necessary, especially when lifestyle recommendations are good enough to prevent them. In order to take the adequate decision about VD supplementation, every clinical individual situation must be analyzed and placed in the correct balance of risk and benefit before prescribing VD supplementation. However, when controversies about clinical decisions are involved, scientists must avoid creating medical barriers about the use of preventive strategies in medicine.

\section{Conclusions}

Although the importance of VD in the regulation of calcium homeostasis in pregnant women is well established, there is now increasing evidence that calcitriol is also important for the prevention of several adverse scenarios that could potentially threaten pregnancy such as infection and preeclampsia. Even though more interventional and basic studies are needed in order to understand the role of VD in pregnancy health and disease, through the information resumed herein it is clear that many of the beneficial effects of calcitriol during gestation involve its immunomodulatory properties as well as its capacity to regulate hormonogenesis. Despite the protective role of VD in pregnancy outcomes and that several epidemiological studies have documented highly prevalent gestational hypovitaminosis D around the world, routine VD screening is still not mandatory and not enough interventional studies have been undertaken to achieve a consensus for VD supplementation in pregnant women, highlighting the need for further studies and establishment of screening guidelines during pregnancy. Given that the human placenta expresses CYP27B1, which catalyzes the local synthesis of calcitriol, the supplementation with VD during pregnancy might be an accessible and safe way to reduce the incidence of some adverse events associated with mother and baby morbidity-mortality, such as PE, GDM, PROM and infections; while, at the same time, both the mother and the child will profit from 
the physiological benefits of calcitriol. Notably, adequate sun exposure, a VD-rich diet and physical activity should always be considered as the first recommendation, while supplementation with cholecalciferol may be advised for persistent VD deficient women.

\section{Acknowledgments}

This work was supported by the Consejo Nacional de Ciencia y Tecnología (CONACyT), México grant number 153862 to LD. AOO is a PhD. student from Posgrado en Ciencias Biológicas at Universidad Nacional Autónoma de México (UNAM) and is receiving a scholarship from CONACyT (231018).

\section{Author Contributions}

All of the authors contributed in the writing and proof-reading of this review article.

\section{Conflicts of Interest}

The authors declare no conflict of interest.

\section{References}

1. Bikle, D. Highlights from the 16th vitamin D workshop, San Francisco, CA, June 11-14, 2013. J. Steroid Biochem. Mol. Biol. 2014, 144, 1-4.

2. Wacker, M.; Holick, M.F. Sunlight and vitamin D: A global perspective for health. Derm. Endocrinol. 2013, 5, 51-108.

3. Nykjaer, A.; Dragun, D.; Walther, D.; Vorum, H.; Jacobsen, C.; Herz, J.; Melsen, F.; Christensen, E.I.; Willnow, T.E. An endocytic pathway essential for renal uptake and activation of the steroid 25-(OH) vitamin D3. Cell 1999, 96, 507-515.

4. Nykjaer, A.; Fyfe, J.C.; Kozyraki, R.; Leheste, J.R.; Jacobsen, C.; Nielsen, M.S.; Verroust, P.J.; Aminoff, M.; de la Chapelle, A.; Moestrup, S.K.; et al. Cubilin dysfunction causes abnormal metabolism of the steroid hormone 25(OH) vitamin D(3). Proc. Natl. Acad. Sci. USA 2001, 98, 13895-13900.

5. Morris, S.M.; Tallquist, M.D.; Rock, C.O.; Cooper, J.A. Dual roles for the dab2 adaptor protein in embryonic development and kidney transport. EMBO J. 2002, 21, 1555-1564.

6. Dusso, A.S.; Brown, A.J.; Slatopolsky, E. Vitamin D. Am. J. Physiol. Ren. Physiol. 2005, 289, 8-28.

7. Costa, J.L.; Eijk, P.P.; van de Wiel, M.A.; ten Berge, D.; Schmitt, F.; Narvaez, C.J.; Welsh, J.; Ylstra, B. Anti-proliferative action of vitamin D in MCF7 is still active after siRNA-VDR knock-down. BMC Genomics 2009, 10, 499.

8. Haussler, M.R.; Jurutka, P.W.; Mizwicki, M.; Norman, A.W. Vitamin D receptor (VDR)-mediated actions of 1alpha,25(OH)(2)vitamin D(3): Genomic and non-genomic mechanisms. Best Pract. Res. Clin. Endocrinol. Metab. 2011, 25, 543-559. 
9. Sylvia, V.L.; Schwartz, Z.; Ellis, E.B.; Helm, S.H.; Gomez, R.; Dean, D.D.; Boyan, B.D. Nongenomic regulation of protein kinase $\mathrm{C}$ isoforms by the vitamin $\mathrm{D}$ metabolites 1 alpha,25-(OH)2D3 and 24R,25-(OH)2D3. J. Cell. Physiol. 1996, 167, 380-393.

10. Beno, D.W.; Brady, L.M.; Bissonnette, M.; Davis, B.H. Protein kinase C and mitogen-activated protein kinase are required for 1,25-dihydroxyvitamin D3-stimulated EGR induction. J. Biol. Chem. 1995, 270, 3642-3647.

11. Berg, J.P.; Haug, E. Vitamin D: A hormonal regulator of the cAMP signaling pathway. Crit. Rev. Biochem. Mol. Biol. 1999, 34, 315-323.

12. Avila, E.; Diaz, L.; Barrera, D.; Halhali, A.; Mendez, I.; Gonzalez, L.; Zuegel, U.; Steinmeyer, A.; Larrea, F. Regulation of vitamin D hydroxylases gene expression by 1,25-dihydroxyvitamin D3 and cyclic AMP in cultured human syncytiotrophoblasts. J. Steroid Biochem. Mol. Biol. 2007, 103, 90-96.

13. Morelli, S.; de Boland, A.R.; Boland, R.L. Generation of inositol phosphates, diacylglycerol and calcium fluxes in myoblasts treated with 1,25-dihydroxyvitamin D3. Biochem. J. 1993, 289, 675-679.

14. Zanello, L.P.; Norman, A.W. 1 alpha,25(OH)2 vitamin D3-mediated stimulation of outward anionic currents in osteoblast-like ROS 17/2.8 cells. Biochem. Biophys. Res. Commun. 1996, 225, 551-556.

15. Nemere, I.; Dormanen, M.C.; Hammond, M.W.; Okamura, W.H.; Norman, A.W. Identification of a specific binding protein for 1 alpha,25-dihydroxyvitamin D3 in basal-lateral membranes of chick intestinal epithelium and relationship to transcaltachia. J. Biol. Chem. 1994, 269, 23750-23756.

16. Quesada, J.M.; Martin-Malo, A.; Santiago, J.; Hervas, F.; Martinez, M.E.; Castillo, D.; Barrio, V.; Aljama, P. Effect of calcitriol on insulin secretion in uraemia. Nephrol. Dial. Transplant. 1990, 5, 1013-1017.

17. Sergeev, I.N.; Rhoten, W.B. 1,25-dihydroxyvitamin D3 evokes oscillations of intracellular calcium in a pancreatic beta-cell line. Endocrinology 1995, 136, 2852-2861.

18. Noda, M.; Vogel, R.L.; Craig, A.M.; Prahl, J.; DeLuca, H.F.; Denhardt, D.T. Identification of a DNA sequence responsible for binding of the 1,25-dihydroxyvitamin D3 receptor and 1,25-dihydroxyvitamin D3 enhancement of mouse secreted phosphoprotein 1 (spp-1 or osteopontin) gene expression. Proc. Natl. Acad. Sci. USA 1990, 87, 9995-9999.

19. Liu, M.; Lee, M.H.; Cohen, M.; Bommakanti, M.; Freedman, L.P. Transcriptional activation of the Cdk inhibitor p21 by vitamin D3 leads to the induced differentiation of the myelomonocytic cell line U937. Genes Dev. 1996, 10, 142-153.

20. Kriebitzsch, C.; Verlinden, L.; Eelen, G.; van Schoor, N.M.; Swart, K.; Lips, P.; Meyer, M.B.; Pike, J.W.; Boonen, S.; Carlberg, C.; et al. 1,25-dihydroxyvitamin D3 influences cellular homocysteine levels in murine preosteoblastic MC3T3-E1 cells by direct regulation of cystathionine beta-synthase. J. Bone Miner. Res. 2011, 26, 2991-3000.

21. Yuan, W.; Pan, W.; Kong, J.; Zheng, W.; Szeto, F.L.; Wong, K.E.; Cohen, R.; Klopot, A.; Zhang, Z.; Li, Y.C. 1,25-dihydroxyvitamin D3 suppresses renin gene transcription by blocking the activity of the cyclic AMP response element in the renin gene promoter. J. Biol. Chem. 2007, 282, 29821-29830. 
22. Garcia-Quiroz, J.; Rivas-Suarez, M.; Garcia-Becerra, R.; Barrera, D.; Martinez-Reza, I.; Ordaz-Rosado, D.; Santos, N.; Villanueva, O.; Santos-Cuevas, C.L.; Avila, E.; et al. Calcitriol reduces thrombospondin-1 and increases vascular endothelial growth factor in breast cancer cells: Implications for tumor angiogenesis. J. Steroid Biochem. Mol. Biol. 2014, 144, 215-222.

23. Liu, P.T.; Stenger, S.; Tang, D.H.; Modlin, R.L. Cutting edge: Vitamin D-mediated human antimicrobial activity against mycobacterium tuberculosis is dependent on the induction of cathelicidin. J. Immunol. 2007, 179, 2060-2063.

24. Wang, T.T.; Nestel, F.P.; Bourdeau, V.; Nagai, Y.; Wang, Q.; Liao, J.; Tavera-Mendoza, L.; Lin, R.; Hanrahan, J.W.; Mader, S.; et al. Cutting edge: 1,25-dihydroxyvitamin D3 is a direct inducer of antimicrobial peptide gene expression. J. Immunol. 2004, 173, 2909-2912.

25. Thompson, P.D.; Jurutka, P.W.; Whitfield, G.K.; Myskowski, S.M.; Eichhorst, K.R.; Dominguez, C.E.; Haussler, C.A.; Haussler, M.R. Liganded VDR induces CYP3A4 in small intestinal and colon cancer cells via DR3 and ER6 vitamin D responsive elements. Biochem. Biophys. Res. Commun. 2002, 299, 730-738.

26. Henry, H.L. Regulation of vitamin D metabolism. Best Pract. Res. Clin. Endocrinol. Metab. 2011, 25, 531-541.

27. Rost, C.R.; Bikle, D.D.; Kaplan, R.A. In vitro stimulation of 25-hydroxycholecalciferol 1 alpha-hydroxylation by parathyroid hormone in chick kidney slices: Evidence for a role for adenosine 3',5'-monophosphate. Endocrinology 1981, 108, 1002-1006.

28. Zierold, C.; Mings, J.A.; DeLuca, H.F. Parathyroid hormone regulates 25-hydroxyvitamin D(3)-24-hydroxylase mRNA by altering its stability. Proc. Natl. Acad. Sci. USA 2001, 98, 13572-13576.

29. Shimada, T.; Kakitani, M.; Yamazaki, Y.; Hasegawa, H.; Takeuchi, Y.; Fujita, T.; Fukumoto, S.; Tomizuka, K.; Yamashita, T. Targeted ablation of FGF23 demonstrates an essential physiological role of FGF23 in phosphate and vitamin D metabolism. J. Clin. Invest. 2004, 113, 561-568.

30. Shimada, T.; Hasegawa, H.; Yamazaki, Y.; Muto, T.; Hino, R.; Takeuchi, Y.; Fujita, T.; Nakahara, K.; Fukumoto, S.; Yamashita, T. FGF-23 is a potent regulator of vitamin D metabolism and phosphate homeostasis. J. Bone Miner. Res. 2004, 19, 429-435.

31. Bikle, D.D. Vitamin D metabolism, mechanism of action, and clinical applications. Chem. Biol. 2014, 21, 319-329.

32. Nesbitt, T.; Drezner, M.K. Insulin-like growth factor-I regulation of renal 25-hydroxyvitamin D-1-hydroxylase activity. Endocrinology 1993, 132, 133-138.

33. Menaa, C.; Vrtovsnik, F.; Friedlander, G.; Corvol, M.; Garabedian, M. Insulin-like growth factor I, a unique calcium-dependent stimulator of 1,25-dihydroxyvitamin D3 production. Studies in cultured mouse kidney cells. J. Biol. Chem. 1995, 270, 25461-25467.

34. Kawashima, H.; Torikai, S.; Kurokawa, K. Calcitonin selectively stimulates 25-hydroxyvitamin D3-1 alpha-hydroxylase in proximal straight tubule of rat kidney. Nature 1981, 291, 327-329.

35. Overbergh, L.; Stoffels, K.; Valckx, D.; Giulietti, A.; Bouillon, R.; Mathieu, C. Regulation of 25-hydroxyvitamin D-1alpha-hydroxylase by IFNgamma in human monocytic THP1 cells. J. Steroid Biochem. Mol. Biol. 2004, 89-90, 453-455. 
36. Gyetko, M.R.; Hsu, C.H.; Wilkinson, C.C.; Patel, S.; Young, E. Monocyte 1 alpha-hydroxylase regulation: Induction by inflammatory cytokines and suppression by dexamethasone and uremia toxin. J. Leukoc. Biol. 1993, 54, 17-22.

37. Pryke, A.M.; Duggan, C.; White, C.P.; Posen, S.; Mason, R.S. Tumor necrosis factor-alpha induces vitamin D-1-hydroxylase activity in normal human alveolar macrophages. J. Cell. Physiol. 1990, 142, 652-656.

38. Adams, J.S.; Gacad, M.A. Characterization of 1 alpha-hydroxylation of vitamin D3 sterols by cultured alveolar macrophages from patients with sarcoidosis. J. Exp. Med. 1985, 161, 755-765.

39. Xie, Z.; Munson, S.J.; Huang, N.; Portale, A.A.; Miller, W.L.; Bikle, D.D. The mechanism of 1,25-dihydroxyvitamin $\mathrm{D}(3)$ autoregulation in keratinocytes. J. Biol. Chem. 2002, 277, 36987-36990.

40. Bikle, D.D.; Pillai, S.; Gee, E.; Hincenbergs, M. Tumor necrosis factor-alpha regulation of 1,25-dihydroxyvitamin D production by human keratinocytes. Endocrinology 1991, 129, 33-38.

41. Bikle, D.D.; Pillai, S.; Gee, E.; Hincenbergs, M. Regulation of 1,25-dihydroxyvitamin D production in human keratinocytes by interferon-gamma. Endocrinology 1989, 124, 655-660.

42. Ren, S.; Nguyen, L.; Wu, S.; Encinas, C.; Adams, J.S.; Hewison, M. Alternative splicing of vitamin D-24-hydroxylase: A novel mechanism for the regulation of extrarenal 1,25-dihydroxyvitamin D synthesis. J. Biol. Chem. 2005, 280, 20604-20611.

43. Novakovic, B.; Sibson, M.; Ng, H.K.; Manuelpillai, U.; Rakyan, V.; Down, T.; Beck, S.; Fournier, T.; Evain-Brion, D.; Dimitriadis, E.; et al. Placenta-specific methylation of the vitamin D 24-hydroxylase gene: Implications for feedback autoregulation of active vitamin D levels at the fetomaternal interface. J. Biol. Chem. 2009, 284, 14838-14848.

44. Chung, I.; Karpf, A.R.; Muindi, J.R.; Conroy, J.M.; Nowak, N.J.; Johnson, C.S.; Trump, D.L. Epigenetic silencing of CYP24 in tumor-derived endothelial cells contributes to selective growth inhibition by calcitriol. J. Biol. Chem. 2007, 282, 8704-8714.

45. Matilainen, J.M.; Malinen, M.; Turunen, M.M.; Carlberg, C.; Vaisanen, S. The number of vitamin D receptor binding sites defines the different vitamin D responsiveness of the CYP24 gene in malignant and normal mammary cells. J. Biol. Chem. 2010, 285, 24174-24183.

46. Noyola-Martinez, N.; Diaz, L.; Zaga-Clavellina, V.; Avila, E.; Halhali, A.; Larrea, F.; Barrera, D. Regulation of CYP27B1 and CYP24A1 gene expression by recombinant pro-inflammatory cytokines in cultured human trophoblasts. J. Steroid Biochem. Mol. Biol. 2014, 144, 106-109.

47. Rosen, C.J.; Adams, J.S.; Bikle, D.D.; Black, D.M.; Demay, M.B.; Manson, J.E.; Murad, M.H.; Kovacs, C.S. The nonskeletal effects of vitamin D: An endocrine society scientific statement. Endocr. Rev. 2012, 33, 456-492.

48. Rubin, L.P.; Yeung, B.; Vouros, P.; Vilner, L.M.; Reddy, G.S. Evidence for human placental synthesis of 24,25-dihydroxyvitamin D3 and 23,25-dihydroxyvitamin D3. Pediatr. Res. 1993, 34, 98-104.

49. Higashi, T.; Mitamura, K.; Ohmi, H.; Yamada, N.; Shimada, K.; Tanaka, K.; Honjo, H. Levels of 24,25-dihydroxyvitamin D3, 25-hydroxyvitamin D3 and 25-hydroxyvitamin D3 3-sulphate in human plasma. Ann. Clin. Biochem. 1999, 36 , 43-47.

50. Lester, G.E.; Gray, T.K.; Lorenc, R.S. Evidence for maternal and fetal differences in vitamin D metabolism. Proc. Soc. Exp. Biol. Med. 1978, 159, 303-307. 
51. Halhali, A.; Diaz, L.; Sanchez, I.; Garabedian, M.; Bourges, H.; Larrea, F. Effects of IGF-I on 1,25-dihydroxyvitamin D(3) synthesis by human placenta in culture. Mol. Hum. Reprod. 1999, 5, 771-776.

52. Brannon, P.M.; Picciano, M.F. Vitamin D in pregnancy and lactation in humans. Ann. Rev. Nutr. 2011, 31, 89-115.

53. Kumar, R.; Cohen, W.R.; Silva, P.; Epstein, F.H. Elevated 1,25-dihydroxyvitamin D plasma levels in normal human pregnancy and lactation. J. Clin. Invest. 1979, 63, 342-344.

54. Seki, K.; Makimura, N.; Mitsui, C.; Hirata, J.; Nagata, I. Calcium-regulating hormones and osteocalcin levels during pregnancy: A longitudinal study. Am. J. Obstet. Gynecol. 1991, 164, 1248-1252.

55. Dahlman, T.; Sjoberg, H.E.; Bucht, E. Calcium homeostasis in normal pregnancy and puerperium. A longitudinal study. Acta Obstet. Gynecol. Scand. 1994, 73, 393-398.

56. Cross, N.A.; Hillman, L.S.; Allen, S.H.; Krause, G.F.; Vieira, N.E. Calcium homeostasis and bone metabolism during pregnancy, lactation, and postweaning: A longitudinal study. Am. J. Clin. Nutr. 1995, 61, 514-523.

57. Kovacs, C.S. Calcium and bone metabolism disorders during pregnancy and lactation. Endocrinol. Metab. Clin. North Am. 2011, 40, 795-826.

58. Moller, U.K.; Streym, S.; Mosekilde, L.; Heickendorff, L.; Flyvbjerg, A.; Frystyk, J.; Jensen, L.T.; Rejnmark, L. Changes in calcitropic hormones, bone markers and insulin-like growth factor I (IGF-I) during pregnancy and postpartum: A controlled cohort study. Osteoporos. Int. 2013, 24, 1307-1320.

59. Ritchie, L.D.; Fung, E.B.; Halloran, B.P.; Turnlund, J.R.; Van Loan, M.D.; Cann, C.E.; King, J.C. A longitudinal study of calcium homeostasis during human pregnancy and lactation and after resumption of menses. Am. J. Clin. Nutr. 1998, 67, 693-701.

60. Tuan, R.S.; Moore, C.J.; Brittingham, J.W.; Kirwin, J.J.; Akins, R.E.; Wong, M. In vitro study of placental trophoblast calcium uptake using JEG-3 human choriocarcinoma cells. J. Cell Sci. 1991, 98, 333-342.

61. Halhali, A.; Figueras, A.G.; Diaz, L.; Avila, E.; Barrera, D.; Hernandez, G.; Larrea, F. Effects of calcitriol on calbindins gene expression and lipid peroxidation in human placenta. J. Steroid Biochem. Mol. Biol. 2010, 121, 448-451.

62. Belkacemi, L.; Zuegel, U.; Steinmeyer, A.; Dion, J.P.; Lafond, J. Calbindin-D28k (CaBP28k) identification and regulation by 1,25-dihydroxyvitamin D3 in human choriocarcinoma cell line JEG-3. Mol. Cell. Endocrinol. 2005, 236, 31-41.

63. Young, B.E.; Cooper, E.M.; McIntyre, A.W.; Kent, T.; Witter, F.; Harris, Z.L.; O’Brien, K.O. Placental vitamin D receptor (VDR) expression is related to neonatal vitamin D status, placental calcium transfer, and fetal bone length in pregnant adolescents. FASEB J. 2014, 28, 2029-2037.

64. Ardawi, M.S.; Nasrat, H.A.; HS, B.A.A. Calcium-regulating hormones and parathyroid hormone-related peptide in normal human pregnancy and postpartum: A longitudinal study. Eur. J. Endocrinol. 1997, 137, 402-409.

65. Ron, M.; Menczel, J.; Schwartz, L.; Palti, Z.; Kidroni, G. Vitamin D3 metabolites in amniotic fluid in relation with maternal and fetal sera in term pregnancies. J. Perinat. Med. 1987, 15, 282-290. 
66. Gupta, M.M.; Kuppuswamy, G.; Subramanian, A.R. Transplacental transfer of 25-hydroxycholecalciferol. Postgrad. Med. J. 1982, 58, 408-410.

67. Wilson, S.G.; Retallack, R.W.; Kent, J.C.; Worth, G.K.; Gutteridge, D.H. Serum free 1,25-dihydroxyvitamin $\mathrm{D}$ and the free 1,25-dihydroxyvitamin $\mathrm{D}$ index during a longitudinal study of human pregnancy and lactation. Clin. Endocrinol. (Oxf.) 1990, 32, 613-622.

68. Paulson, S.K.; Ford, K.K.; Langman, C.B. Pregnancy does not alter the metabolic clearance of 1,25-dihydroxyvitamin D in rats. Am. J. Physiol. 1990, 258, E158-E162.

69. Weisman, Y.; Harell, A.; Edelstein, S.; David, M.; Spirer, Z.; Golander, A. 1 alpha, 25-dihydroxyvitamin D3 and 24,25-dihydroxyvitamin D3 in vitro synthesis by human decidua and placenta. Nature 1979, 281, 317-319.

70. Diaz, L.; Sanchez, I.; Avila, E.; Halhali, A.; Vilchis, F.; Larrea, F. Identification of a 25-hydroxyvitamin D3 1alpha-hydroxylase gene transcription product in cultures of human syncytiotrophoblast cells. J. Clin. Endocrinol. Metab. 2000, 85, 2543-2549.

71. Whitsett, J.A.; Ho, M.; Tsang, R.C.; Norman, E.J.; Adams, K.G. Synthesis of 1,25-dihydroxyvitamin D3 by human placenta in vitro. J. Clin. Endocrinol. Metab. 1981, 53, 484-488.

72. Kirby, B.J.; Ma, Y.; Martin, H.M.; Buckle Favaro, K.L.; Karaplis, A.C.; Kovacs, C.S. Upregulation of calcitriol during pregnancy and skeletal recovery after lactation do not require parathyroid hormone. J. Bone Miner. Res. 2013, 28, 1987-2000.

73. Sanz-Salvador, L.; Garcia-Perez, M.A.; Tarin, J.J.; Cano, A. Endocrinology in pregnancy: Bone metabolic changes during pregnancy: A period of vulnerability to osteoporosis and fracture. Eur. J. Endocrinol. 2015, 172, 53-65.

74. Simmonds, C.S.; Kovacs, C.S. Role of parathyroid hormone (PTH) and PTH-related protein (PTHrP) in regulating mineral homeostasis during fetal development. Crit. Rev. Eukaryot. Gene Expr. 2010, 20, 235-273.

75. Weisman, Y.; Vargas, A.; Duckett, G.; Reiter, E.; Root, A.W. Synthesis of 1,25-dihydroxyvitamin D in the nephrectomized pregnant rat. Endocrinology 1978, 103, 1992-1996.

76. Blum, M.; Weisman, Y.; Turgeman, S.; Cabili, S.; Wollman, Y.; Peer, G.; Stern, N.; Silverberg, D.; Schwartz, D.; Iaina, A. Pregnancy decreases immunoreactive parathyroid hormone level in rats with chronic renal failure. Clin. Sci. (Lond.) 1999, 96, 427-430.

77. Zehnder, D.; Bland, R.; Williams, M.C.; McNinch, R.W.; Howie, A.J.; Stewart, P.M.; Hewison, M. Extrarenal expression of 25-hydroxyvitamin D(3)-1 alpha-hydroxylase. J. Clin. Endocrinol. Metab. 2001, 86, 888-894.

78. Zehnder, D.; Evans, K.N.; Kilby, M.D.; Bulmer, J.N.; Innes, B.A.; Stewart, P.M.; Hewison, M. The ontogeny of 25-hydroxyvitamin $\mathrm{D}(3)$ 1alpha-hydroxylase expression in human placenta and decidua. Am. J. Pathol. 2002, 161, 105-114.

79. Evans, K.N.; Bulmer, J.N.; Kilby, M.D.; Hewison, M. Vitamin D and placental-decidual function. J. Soc. Gynecol. Investig. 2004, 11, 263-271.

80. Bikle, D.D.; Gee, E.; Halloran, B.; Haddad, J.G. Free 1,25-dihydroxyvitamin D levels in serum from normal subjects, pregnant subjects, and subjects with liver disease. J. Clin. Invest. 1984, 74, 1966-1971. 
81. Chun, R.F.; Peercy, B.E.; Orwoll, E.S.; Nielson, C.M.; Adams, J.S.; Hewison, M. Vitamin D and DBP: The free hormone hypothesis revisited. J. Steroid Biochem. Mol. Biol. 2014, 144, 132-137.

82. Burke, K.A.; Jauniaux, E.; Burton, G.J.; Cindrova-Davies, T. Expression and immunolocalisation of the endocytic receptors megalin and cubilin in the human yolk sac and placenta across gestation. Placenta 2013, 34, 1105-1109.

83. Akour, A.A.; Gerk, P.; Kennedy, M.J. Megalin expression in human term and preterm placental villous tissues: Effect of gestational age and sample processing and storage time. J. Pharmacol. Toxicol. Methods 2014, doi:10.1016/j.vascn.2014.10.001.

84. Christensen, E.I.; Birn, H. Megalin and cubilin: Multifunctional endocytic receptors. Nat. Rev. Mol. Cell Biol. 2002, 3, 256-266.

85. Safadi, F.F.; Thornton, P.; Magiera, H.; Hollis, B.W.; Gentile, M.; Haddad, J.G.; Liebhaber, S.A.; Cooke, N.E. Osteopathy and resistance to vitamin D toxicity in mice null for vitamin D binding protein. J. Clin. Invest. 1999, 103, 239-251.

86. Johnson, J.A.; Grande, J.P.; Roche, P.C.; Kumar, R. Immunohistochemical detection and distribution of the 1,25-dihydroxyvitamin D3 receptor in rat reproductive tissues. Histochem. Cell Biol. 1996, 105, 7-15.

87. Shahbazi, M.; Jeddi-Tehrani, M.; Zareie, M.; Salek-Moghaddam, A.; Akhondi, M.M.; Bahmanpoor, M.; Sadeghi, M.R.; Zarnani, A.H. Expression profiling of vitamin D receptor in placenta, decidua and ovary of pregnant mice. Placenta 2011, 32, 657-664.

88. Zarnani, A.H.; Shahbazi, M.; Salek-Moghaddam, A.; Zareie, M.; Tavakoli, M.; Ghasemi, J.; Rezania, S.; Moravej, A.; Torkabadi, E.; Rabbani, H.; et al. Vitamin D3 receptor is expressed in the endometrium of cycling mice throughout the estrous cycle. Fertil. Steril. 2010, 93, 2738-2743.

89. Evans, K.N.; Nguyen, L.; Chan, J.; Innes, B.A.; Bulmer, J.N.; Kilby, M.D.; Hewison, M. Effects of 25-hydroxyvitamin D3 and 1,25-dihydroxyvitamin D3 on cytokine production by human decidual cells. Biol. Reprod. 2006, 75, 816-822.

90. Liu, N.; Kaplan, A.T.; Low, J.; Nguyen, L.; Liu, G.Y.; Equils, O.; Hewison, M. Vitamin D induces innate antibacterial responses in human trophoblasts via an intracrine pathway. Biol. Reprod. 2009, 80, 398-406.

91. Diaz, L.; Noyola-Martinez, N.; Barrera, D.; Hernandez, G.; Avila, E.; Halhali, A.; Larrea, F. Calcitriol inhibits TNF-alpha-induced inflammatory cytokines in human trophoblasts. J. Reprod. Immunol. 2009, 81, 17-24.

92. Noyola-Martinez, N.; Diaz, L.; Avila, E.; Halhali, A.; Larrea, F.; Barrera, D. Calcitriol downregulates TNF-alpha and IL-6 expression in cultured placental cells from preeclamptic women. Cytokine 2013, 61, 245-250.

93. Olmos-Ortiz, A.; Noyola-Martinez, N.; Barrera, D.; Zaga-Clavellina, V.; Avila, E.; Halhali, A.; Biruete, B.; Larrea, F.; Diaz, L. IL-10 inhibits while calcitriol reestablishes placental antimicrobial peptides gene expression. J. Steroid Biochem. Mol. Biol. 2014, doi:10.1016/ j.jsbmb.2014.07.012.

94. Halhali, A.; Acker, G.M.; Garabedian, M. 1,25-dihydroxyvitamin D3 induces in vivo the decidualization of rat endometrial cells. J. Reprod. Fertil. 1991, 91, 59-64. 
95. Barrera, D.; Avila, E.; Hernandez, G.; Halhali, A.; Biruete, B.; Larrea, F.; Diaz, L. Estradiol and progesterone synthesis in human placenta is stimulated by calcitriol. J. Steroid Biochem. Mol. Biol. 2007, 103, 529-532.

96. Barrera, D.; Avila, E.; Hernandez, G.; Mendez, I.; Gonzalez, L.; Halhali, A.; Larrea, F.; Morales, A.; Diaz, L. Calcitriol affects hCG gene transcription in cultured human syncytiotrophoblasts. Reprod. Biol. Endocrinol. 2008, 6, 3.

97. Stephanou, A.; Ross, R.; Handwerger, S. Regulation of human placental lactogen expression by 1,25-dihydroxyvitamin D3. Endocrinology 1994, 135, 2651-2656.

98. Binkley, N.; Ramamurthy, R.; Krueger, D. Low vitamin D status: Definition, prevalence, consequences, and correction. Endocrinol. Metab. Clin. North Am. 2010, 39, 287-301.

99. Levine, B.S.; Song, M. Pharmacokinetics and efficacy of pulse oral versus intravenous calcitriol in hemodialysis patients. J. Am. Soc. Nephrol. 1996, 7, 488-496.

100. Batchelor, A.J.; Watson, G.; Compston, J.E. Changes in plasma half-life and clearance of 3h-25-hydroxyvitamin D3 in patients with intestinal malabsorption. Gut 1982, 23, 1068-1071.

101. Dawson-Hughes, B.; Heaney, R.P.; Holick, M.F.; Lips, P.; Meunier, P.J.; Vieth, R. Estimates of optimal vitamin D status. Osteoporos. Int. 2005, 16, 713-716.

102. Pepe, J.; Romagnoli, E.; Nofroni, I.; Pacitti, M.T.; de Geronimo, S.; Letizia, C.; Tonnarini, G.; Scarpiello, A.; D’Erasmo, E.; Minisola, S. Vitamin D status as the major factor determining the circulating levels of parathyroid hormone: A study in normal subjects. Osteoporos. Int. 2005, 16, 805-812.

103. Heaney, R.P. Functional indices of vitamin D status and ramifications of vitamin D deficiency. Am. J. Clin. Nutr. 2004, 80, 1706-1709.

104. Vigano, P.; Lattuada, D.; Mangioni, S.; Ermellino, L.; Vignali, M.; Caporizzo, E.; Panina-Bordignon, P.; Besozzi, M.; di Blasio, A.M. Cycling and early pregnant endometrium as a site of regulated expression of the vitamin D system. J. Mol. Endocrinol. 2006, 36, 415-424.

105. Barrera, D.; Noyola-Martinez, N.; Avila, E.; Halhali, A.; Larrea, F.; Diaz, L. Calcitriol inhibits interleukin-10 expression in cultured human trophoblasts under normal and inflammatory conditions. Cytokine 2012, 57, 316-321.

106. Avila, E.; Garcia-Becerra, R.; Rodriguez-Rasgado, J.A.; Diaz, L.; Ordaz-Rosado, D.; Zugel, U.; Steinmeyer, A.; Barrera, D.; Halhali, A.; Larrea, F.; et al. Calcitriol down-regulates human ether a go-go 1 potassium channel expression in cervical cancer cells. Anticancer Res. 2010, 30, 2667-2672.

107. Delvin, E.E.; Gagnon, L.; Arabian, A.; Gibb, W. Influence of calcitriol on prolactin and prostaglandin production by human decidua. Mol. Cell Endocrinol. 1990, 71, 177-183.

108. Narahara, H.; Miyakawa, I.; Johnston, J.M. The inhibitory effect of 1,25-dihydroxyvitamin D3 on the secretion of platelet-activating factor acetylhydrolase by human decidual macrophages. $J$. Clin. Endocrinol. Metab. 1995, 80, 3121-3126.

109. Daftary, G.S.; Taylor, H.S. Endocrine regulation of HOX genes. Endocr. Rev. 2006, 27, 331-355.

110. Holick, M.F.; Binkley, N.C.; Bischoff-Ferrari, H.A.; Gordon, C.M.; Hanley, D.A.; Heaney, R.P.; Murad, M.H.; Weaver, C.M. Evaluation, treatment, and prevention of vitamin D deficiency: An Endocrine Society clinical practice guideline. J. Clin. Endocrinol. Metab. 2011, 96, 1911-1930. 
111. Ross, A.C.; Manson, J.E.; Abrams, S.A.; Aloia, J.F.; Brannon, P.M.; Clinton, S.K.; Durazo-Arvizu, R.A.; Gallagher, J.C.; Gallo, R.L.; Jones, G.; et al. The 2011 Report on dietary reference intakes for calcium and vitamin D from the Institute of Medicine: What clinicians need to know. J. Clin. Endocrinol. Metab. 2011, 96, 53-58.

112. Aghajafari, F.; Nagulesapillai, T.; Ronksley, P.E.; Tough, S.C.; O’Beirne, M.; Rabi, D.M. Association between maternal serum 25-hydroxyvitamin D level and pregnancy and neonatal outcomes: Systematic review and meta-analysis of observational studies. BMJ 2013, 346, 1169.

113. Barrett, H.; McElduff, A. Vitamin D and pregnancy: An old problem revisited. Best Pract. Res. Clin. Endocrinol. Metab. 2010, 24, 527-529.

114. Bodnar, L.M.; Simhan, H.N. Vitamin D may be a link to black-white disparities in adverse birth outcomes. Obstet. Gynecol. Surv. 2010, 65, 273-284.

115. Christesen, H.T.; Falkenberg, T.; Lamont, R.F.; Jorgensen, J.S. The impact of vitamin D on pregnancy: A systematic review. Acta Obstet. Gynecol. Scandinav. 2012, 91, 1357-1367.

116. Nassar, N.; Halligan, G.H.; Roberts, C.L.; Morris, J.M.; Ashton, A.W. Systematic review of first-trimester vitamin D normative levels and outcomes of pregnancy. Am. J. Obstet. Gynecol. 2011, 205, 208.e201-208.e207.

117. Thorne-Lyman, A.; Fawzia, W.W. Vitamin D during pregnancy and maternal, neonatal and infant health outcomes: A systematic review and meta-analysis. Paediatr. Perinat. Epidemiol. 2012, 26, 75-90.

118. Urrutia, R.P.; Thorp, J.M. Vitamin D in pregnancy: Current concepts. Curr. Opin. Obstet. Gynecol. 2012, 24, 57-64.

119. Wei, S.Q.; Qi, H.P.; Luo, Z.C.; Fraser, W.D. Maternal vitamin D status and adverse pregnancy outcomes: A systematic review and meta-analysis. J Matern. Fetal Neonatal Med. 2013, 26, 889-899.

120. Report of the National high blood pressure Education Program Working Group on high blood pressure in pregnancy. Am. J. Obstet. Gynecol. 2000, 183, 1-22.

121. ACOG practice bulletin. Diagnosis and management of preeclampsia and eclampsia. Number 33, january 2002. American College of Obstetricians and Gynecologists. Int. J. Gynaecol. Obstet. 2002, 77, 67-75.

122. Baumwell, S.; Karumanchi, S.A. Pre-eclampsia: Clinical manifestations and molecular mechanisms. Nephron Clin. Pract. 2007, 106, c72-c81.

123. Palei, A.C.; Spradley, F.T.; Warrington, J.P.; George, E.M.; Granger, J.P. Pathophysiology of hypertension in pre-eclampsia: A lesson in integrative physiology. Acta Physiol. 2013, 208, 224-233.

124. Gernand, A.D.; Bodnar, L.M.; Klebanoff, M.A.; Parks, W.T.; Simhan, H.N. Maternal serum 25-hydroxyvitamin D and placental vascular pathology in a multicenter US cohort. Am. J. Clin. Nutr. 2013, 98, 383-388.

125. Halhali, A.; Bourges, H.; Carrillo, A.; Garabedian, M. Lower circulating insulin-like growth factor I and 1,25-dihydroxyvitamin D levels in preeclampsia. Rev. Invest. Clin. 1995, 47, 259-266.

126. Halhali, A.; Diaz, L.; Avila, E.; Ariza, A.C.; Garabedian, M.; Larrea, F. Decreased fractional urinary calcium excretion and serum 1,25-dihydroxyvitamin D and IGF-I levels in preeclampsia. J. Steroid Biochem. Mol. Biol. 2007, 103, 803-806. 
127. Halhali, A.; Tovar, A.R.; Torres, N.; Bourges, H.; Garabedian, M.; Larrea, F. Preeclampsia is associated with low circulating levels of insulin-like growth factor I and 1,25-dihydroxyvitamin D in maternal and umbilical cord compartments. J. Clin. Endocrinol. Metab. 2000, 85, 1828-1833.

128. Diaz, E.; Halhali, A.; Luna, C.; Diaz, L.; Avila, E.; Larrea, F. Newborn birth weight correlates with placental zinc, umbilical insulin-like growth factor I, and leptin levels in preeclampsia. Arch. Med. Res. 2002, 33, 40-47.

129. Robinson, C.J.; Alanis, M.C.; Wagner, C.L.; Hollis, B.W.; Johnson, D.D. Plasma 25-hydroxyvitamin D levels in early-onset severe preeclampsia. Am. J. Obstet. Gynecol. 2010, 203, 366.e361-366.e366.

130. Xu, L.; Lee, M.; Jeyabalan, A.; Roberts, J.M. The relationship of hypovitaminosis D and IL-6 in preeclampsia. Am. J. Obstet. Gynecol. 2014, 210, 149.e141-149.e147.

131. Ullah, M.I.; Koch, C.A.; Tamanna, S.; Rouf, S.; Shamsuddin, L. Vitamin D deficiency and the risk of preeclampsia and eclampsia in Bangladesh. Horm. Metab. Res. 2013, 45, 682-687.

132. Wei, S.Q.; Audibert, F.; Luo, Z.C.; Nuyt, A.M.; Masse, B.; Julien, P.; Fraser, W.D. Maternal plasma 25-hydroxyvitamin D levels, angiogenic factors, and preeclampsia. Am. J. Obstet. Gynecol. 2013, 208, 390.e391-390.e396.

133. Baker, A.M.; Haeri, S.; Camargo, C.A., Jr.; Espinola, J.A.; Stuebe, A.M. A nested case-control study of midgestation vitamin D deficiency and risk of severe preeclampsia. J. Clin. Endocrinol. Metab. 2010, 95, 5105-5109.

134. Bodnar, L.M.; Catov, J.M.; Simhan, H.N.; Holick, M.F.; Powers, R.W.; Roberts, J.M. Maternal vitamin D deficiency increases the risk of preeclampsia. J. Clin. Endocrinol. Metab. 2007, 92, 3517-3522.

135. Abedi, P.; Mohaghegh, Z.; Afshary, P.; Latifi, M. The relationship of serum vitamin D with pre-eclampsia in the iranian women. Matern. Child. Nutr. 2014, 10, 206-212.

136. Diaz, L.; Arranz, C.; Avila, E.; Halhali, A.; Vilchis, F.; Larrea, F. Expression and activity of 25-hydroxyvitamin D-1 alpha-hydroxylase are restricted in cultures of human syncytiotrophoblast cells from preeclamptic pregnancies. J. Clin. Endocrinol. Metab. 2002, 87, 3876-3882.

137. Bodnar, L.M.; Simhan, H.N.; Catov, J.M.; Roberts, J.M.; Platt, R.W.; Diesel, J.C.; Klebanoff, M.A. Maternal vitamin D status and the risk of mild and severe preeclampsia. Epidemiology 2014, 25, 207-214.

138. Woodham, P.C.; Brittain, J.E.; Baker, A.M.; Leann Long, D.; Haeri, S.; Camargo, C.A.J.; Boggess, K.A.; Stuebe, A.M. Midgestation maternal serum 25-hydroxyvitamin D level and soluble fms-like tyrosine kinase 1/placental growth factor ratio as predictors of severe preeclampsia. Hypertension 2011, 58, 1120-1125.

139. Haugen, M.; Brantsæter, A.L.; Trogstad, L.; Alexander, J.; Roth, C.; Magnus, P.; Meltzera, H.M. Vitamin D supplementation and reduced risk of preeclampsia in nulliparous women. Epidemiology 2009, 20, 720-726.

140. Hyppönen, E.; Cavadino, A.; Williams, D.; Fraser, A.; Vereczkey, A.; Fraser, W.D.; Bánhidy, F.; Lawlor, D.; Czeizel, A.E. Vitamin D and pre-eclampsia: Original data, systematic review and meta-analysis. Ann. Nutr. Metab. 2013, 63, 331-340. 
141. Tabesh, M.; Salehi-Abargouei, A.; Esmaillzadeh, A. Maternal vitamin D status and risk of pre-eclampsia: A systematic review and meta-analysis. J. Clin. Endocrinol. Metab. 2013, 98, 3165-3173.

142. Shand, A.W.; Nassar, N.; von Dadelszen, P.; Innis, S.M.; Green, T.J. Maternal vitamin D status in pregnancy and adverse pregnancy outcomes in a group at high risk for pre-eclampsia. BJOG 2010, 117, 1593-1598.

143. Powe, C.E.; Seely, E.W.; Rana, S.; Bhan, I.; Ecker, J.; Karumanchi, S.A.; Thadhani, R. First trimester vitamin D, vitamin D binding protein, and subsequent preeclampsia. Hypertension 2010, 56, 758-763.

144. Mashburn, J. Vaginal infections update. J. Midwifery Womens Health 2012, 57, 629-634.

145. Denney, J.M.; Culhane, J.F. Bacterial vaginosis: A problematic infection from both a perinatal and neonatal perspective. Semin. Fetal Neonatal Med. 2009, 14, 200-203.

146. Allsworth, J.E.; Peipert, J.F. Prevalence of bacterial vaginosis: 2001-2004 National Health and Nutrition Examination Survey data. Obstet. Gynecol. 2007, 109, 114-120.

147. Prietl, B.; Treiber, G.; Pieber, T.R.; Amrein, K. Vitamin D and immune function. Nutrients 2013, 5, 2502-2521.

148. Hewison, M. Vitamin D and immune function: An overview. Proc. Nutr. Soc. 2012, 71, 50-61.

149. Bodnar, L.M.; Krohn, M.A.; Simhan, H.N. Maternal vitamin D deficiency is associated with bacterial vaginosis in the first trimester of pregnancy. J. Nutr. 2009, 139, 1157-1161.

150. Dunlop, A.L.; Taylor, R.N.; Tangpricha, V.; Fortunato, S.; Menon, R. Maternal vitamin D, folate, and polyunsaturated fatty acid status and bacterial vaginosis during pregnancy. Infect. Dis. Obstet. Gynecol. 2011, 2011, 216217.

151. Hensel, K.J.; Randis, T.M.; Gelber, S.E.; Ratner, A.J. Pregnancy-specific association of vitamin D deficiency and bacterial vaginosis. Am. J. Obstet. Gynecol. 2011, 204, 41-49.

152. Rustveld, L.O.; Kelsey, S.F.; Sharma, R. Association between maternal infections and preeclampsia: A systematic review of epidemiologic studies. Matern. Child. Health J. 2008, 12, 223-242.

153. Hertting, O.; Holm, A.; Luthje, P.; Brauner, H.; Dyrdak, R.; Jonasson, A.F.; Wiklund, P.; Chromek, M.; Brauner, A. Vitamin D induction of the human antimicrobial peptide cathelicidin in the urinary bladder. PLoS One 2010, 5, 15580.

154. Boggess, K.A.; Espinola, J.A.; Moss, K.; Beck, J.; Offenbacher, S.; Camargo, C.A. Vitamin D status and periodontal disease among pregnant women. J. Periodontol. 2011, 82, 195-200.

155. Lowry, M.B.; Guo, C.; Borregaard, N.; Gombart, A.F. Regulation of the human cathelicidin antimicrobial peptide gene by 1alpha,25-dihydroxyvitamin D in primary immune cells. J. Steroid Biochem. Mol. Biol. 2014, 143, 183-191.

156. Mendez-Samperio, P. The human cathelicidin hCAP18/LL-37: A multifunctional peptide involved in mycobacterial infections. Peptides 2010, 31, 1791-1798.

157. Campbell, G.R.; Spector, S.A. Autophagy induction by vitamin D inhibits both mycobacterium tuberculosis and human immunodeficiency virus type 1. Autophagy 2012, 8, 1523-1525.

158. Campbell, G.R.; Spector, S.A. Vitamin D inhibits human immunodeficiency virus type 1 and mycobacterium tuberculosis infection in macrophages through the induction of autophagy. PLoS Pathog. 2012, 8, 1002689. 
159. Wan, M.; van der Does, A.M.; Tang, X.; Lindbom, L.; Agerberth, B.; Haeggstrom, J.Z. Antimicrobial peptide LL-37 promotes bacterial phagocytosis by human macrophages. J. Leukoc. Biol. 2014, 95, 971-981.

160. Frew, L.; Stock, S.J. Antimicrobial peptides and pregnancy. Reproduction 2011, 141, 725-735.

161. Thota, C.; Farmer, T.; Garfield, R.E.; Menon, R.; Al-Hendy, A. Vitamin D elicits anti-inflammatory response, inhibits contractile-associated proteins, and modulates Toll-like receptors in human myometrial cells. Reprod. Sci. 2013, 20, 463-475.

162. Bodnar, L.M.; Rouse, D.J.; Momirova, V.; Peaceman, A.M.; Sciscione, A.; Spong, C.Y.; Varner, M.W.; Malone, F.D.; Iams, J.D.; Mercer, B.M.; et al. Maternal 25-hydroxyvitamin D and preterm birth in twin gestations. Obstet. Gynecol. 2013, 122, 91-98.

163. Thorp, J.M.; Camargo, C.A.; McGee, P.L.; Harper, M.; Klebanoff, M.A.; Sorokin, Y.; Varner, M.W.; Wapner, R.J.; Caritis, S.N.; Iams, J.D.; et al. Vitamin D status and recurrent preterm birth: A nested case-control study in high-risk women. BJOG 2012, 119, 1617-1623.

164. American Diabetes Association. Gestational diabetes mellitus. Diabetes Care 2003, 26 (Suppl. 1), 103-105.

165. American Diabetes Association. Standards of medical care in diabetes--2012. Diabetes Care 2012, 35 (Suppl. 1), 11-63.

166. Wang, Z.; Kanguru, L.; Hussein, J.; Fitzmaurice, A.; Ritchie, K. Incidence of adverse outcomes associated with gestational diabetes mellitus in low- and middle-income countries. Int. J. Gynaecol. Obstet. 2013, 121, 14-19.

167. Wendland, E.M.; Torloni, M.R.; Falavigna, M.; Trujillo, J.; Dode, M.A.; Campos, M.A.; Duncan, B.B.; Schmidt, M.I. Gestational diabetes and pregnancy outcomes-A systematic review of the world health organization (WHO) and the International Association of Diabetes in Pregnancy Study Groups (IADPSG) diagnostic criteria. BMC Pregnancy Childbirth 2012, 12, 23.

168. Norman, A.W.; Frankel, J.B.; Heldt, A.M.; Grodsky, G.M. Vitamin D deficiency inhibits pancreatic secretion of insulin. Science 1980, 209, 823-825.

169. Cho, G.J.; Hong, S.C.; Oh, M.J.; Kim, H.J. Vitamin D deficiency in gestational diabetes mellitus and the role of the placenta. Am. J. Obstet. Gynecol. 2013, 209, 560 e561-560 e568.

170. Clifton-Bligh, R.J.; McElduff, P.; McElduff, A. Maternal vitamin D deficiency, ethnicity and gestational diabetes. Diabetes Med. 2008, 25, 678-684.

171. Parlea, L.; Bromberg, I.L.; Feig, D.S.; Vieth, R.; Merman, E.; Lipscombe, L.L. Association between serum 25-hydroxyvitamin $\mathrm{D}$ in early pregnancy and risk of gestational diabetes mellitus. Diabetes Med. 2012, 29, 25-32.

172. Soheilykhah, S.; Mojibian, M.; Rashidi, M.; Rahimi-Saghand, S.; Jafari, F. Maternal vitamin D status in gestational diabetes mellitus. Nutr. Clin. Pract. 2010, 25, 524-527.

173. Zhang, C.; Qiu, C.; Hu, F.B.; David, R.M.; van Dam, R.M.; Bralley, A.; Williams, M.A. Maternal plasma 25-hydroxyvitamin $\mathrm{D}$ concentrations and the risk for gestational diabetes mellitus. PLoS One 2008, 3, 3753.

174. Zuhur, S.S.; Erol, R.S.; Kuzu, I.; Altuntas, Y. The relationship between low maternal serum 25-hydroxyvitamin D levels and gestational diabetes mellitus according to the severity of 25-hydroxyvitamin D deficiency. Clinics (Sao Paulo) 2013, 68, 658-664. 
175. Maghbooli, Z.; Hossein-Nezhad, A.; Karimi, F.; Shafaei, A.R.; Larijani, B. Correlation between vitamin D3 deficiency and insulin resistance in pregnancy. Diabetes Metab. Res. Rev. 2008, 24, 27-32.

176. Napartivaumnuay, N.; Niramitmahapanya, S.; Deerochanawong, C.; Suthornthepavarakul, T.; Sarinnapakorn, V.; Jaruyawongs, P. Maternal 25 hydroxyvitamin D level and its correlation in thai gestational diabetes patients. J. Med. Assoc. Thail. 2013, 96 (Suppl. 3), 69-76.

177. Burris, H.H.; Rifas-Shiman, S.L.; Kleinman, K.; Litonjua, A.A.; Huh, S.Y.; Rich-Edwards, J.W.; Camargo, C.A., Jr.; Gillman, M.W. Vitamin D deficiency in pregnancy and gestational diabetes mellitus. Am. J. Obstet. Gynecol. 2012, 207, 182.e181-182.e188.

178. Wang, O.; Nie, M.; Hu, Y.Y.; Zhang, K.; Li, W.; Ping, F.; Liu, J.T.; Chen, L.M.; Xing, X.P. Association between vitamin $\mathrm{D}$ insufficiency and the risk for gestational diabetes mellitus in pregnant chinese women. Biomed. Environ. Sci. 2012, 25, 399-406.

179. Poel, Y.H.; Hummel, P.; Lips, P.; Stam, F.; van der Ploeg, T.; Simsek, S. Vitamin D and gestational diabetes: A systematic review and meta-analysis. Eur. J. Intern. Med. 2012, 23, 465-469.

180. Senti, J.; Thiele, D.K.; Anderson, C.M. Maternal vitamin D status as a critical determinant in gestational diabetes. J. Obstet. Gynecol. Neonatal. Nurs. 2012, 41, 328-338.

181. Lau, S.L.; Gunton, J.E.; Athayde, N.P.; Byth, K.; Cheung, N.W. Serum 25-hydroxyvitamin D and glycated haemoglobin levels in women with gestational diabetes mellitus. Med. J. Aust. 2011, 194, 334-337.

182. Makgoba, M.; Nelson, S.M.; Savvidou, M.; Messow, C.M.; Nicolaides, K.; Sattar, N. First-trimester circulating 25-hydroxyvitamin D levels and development of gestational diabetes mellitus. Diabetes Care 2011, 34, 1091-1093.

183. McLeod, D.S.; Warner, J.V.; Henman, M.; Cowley, D.; Gibbons, K.; McIntyre, H.D. Associations of serum vitamin D concentrations with obstetric glucose metabolism in a subset of the Hyperglycemia and Adverse Pregnancy Outcome (HAPO) study cohort. Diabetes Med. 2012, 29, 199-204.

184. Walsh, J.M.; McGowan, C.A.; Kilbane, M.; McKenna, M.J.; McAuliffe, F.M. The relationship between maternal and fetal vitamin D, insulin resistance, and fetal growth. Reprod. Sci. 2013, 20, 536-541.

185. Jelsma, J.G.; van Poppel, M.N.; Galjaard, S.; Desoye, G.; Corcoy, R.; Devlieger, R.; van Assche, A.; Timmerman, D.; Jans, G.; Harreiter, J.; et al. Dali: Vitamin D and lifestyle intervention for gestational diabetes mellitus (GDM) prevention: An european multicentre, randomised trial-study protocol. BMC Pregnancy Childbirth 2013, 13, 142.

186. Asemi, Z.; Hashemi, T.; Karamali, M.; Samimi, M.; Esmaillzadeh, A. Effects of vitamin D supplementation on glucose metabolism, lipid concentrations, inflammation, and oxidative stress in gestational diabetes: A double-blind randomized controlled clinical trial. Am. J. Clin. Nutr. 2013, 98, 1425-1432.

187. Mozaffari-Khosravi, H.; Hosseinzadeh-Shamsi-Anar, M.; Salami, M.A.; Hadinedoushan, H.; Mozayan, M.R. Effects of a single post-partum injection of a high dose of vitamin D on glucose tolerance and insulin resistance in mothers with first-time gestational diabetes mellitus. Diabetes Med. 2012, 29, 36-42. 
188. Baker, A.M.; Haeri, S.; Camargo, C.A., Jr.; Stuebe, A.M.; Boggess, K.A. First-trimester maternal vitamin D status and risk for gestational diabetes (GDM) a nested case-control study. Diabetes Metab. Res. Rev. 2012, 28, 164-168.

189. Savvidou, M.D.; Akolekar, R.; Samaha, R.B.; Masconi, A.P.; Nicolaides, K.H. Maternal serum 25-hydroxyvitamin D levels at 11(+0) -13(+6) weeks in pregnant women with diabetes mellitus and in those with macrosomic neonates. BJOG 2011, 118, 951-955.

190. Farrant, H.J.; Krishnaveni, G.V.; Hill, J.C.; Boucher, B.J.; Fisher, D.J.; Noonan, K.; Osmond, C.; Veena, S.R.; Fall, C.H. Vitamin D insufficiency is common in indian mothers but is not associated with gestational diabetes or variation in newborn size. Eur. J. Clin. Nutr. 2009, 63, 646-652.

191. Tomedi, L.E.; Simhan, H.N.; Bodnar, L.M. Early-pregnancy maternal vitamin D status and maternal hyperglycaemia. Diabetes Med. 2013, 30, 1033-1039.

192. Mirzaei, K.; Hossein-Nezhad, A.; Keshavarz, S.A.; Eshaghi, S.M.; Koohdani, F.; Saboor-Yaraghi, A.A.; Hosseini, S.; Tootee, A.; Djalali, M. Insulin resistance via modification of PGC1alpha function identifying a possible preventive role of vitamin D analogues in chronic inflammatory state of obesity. A double blind clinical trial study. Minerva Med. 2014, 105, 63-78.

193. Alkharfy, K.M.; Al-Daghri, N.M.; Yakout, S.M.; Hussain, T.; Mohammed, A.K.; Krishnaswamy, S. Influence of vitamin D treatment on transcriptional regulation of insulin-sensitive genes. Metab. Syndr. Relat. Disord. 2013, 11, 283-288.

194. Manna, P.; Jain, S.K. Vitamin D up-regulates glucose transporter 4 (GLUT4) translocation and glucose utilization mediated by cystathionine-gamma-lyase (CSE) activation and H2Ss formation in 3T3L1 adipocytes. J. Biol. Chem. 2012, 287, 42324-42332.

195. Meerza, D.; Naseem, I.; Ahmed, J. Effect of 1, 25(OH)(2) vitamin D(3) on glucose homeostasis and DNA damage in type 2 diabetic mice. J. Diabetes Complicat. 2012, 26, 363-368.

196. Zhang, J.; Merialdi, M.; Platt, L.D.; Kramer, M.S. Defining normal and abnormal fetal growth: Promises and challenges. Am. J. Obstet. Gynecol. 2010, 202, 522-528.

197. Mayer, C.; Joseph, K.S. Fetal growth: A review of terms, concepts and issues relevant to obstetrics. Ultrasound Obstet. Gynecol. 2013, 41, 136-145.

198. Burris, H.H.; Mitchell, A.A.; Werler, M.M. Periconceptional multivitamin use and infant birth weight disparities. Ann. Epidemiol. 2010, 20, 233-240.

199. Kovacs, C.S. Maternal vitamin D deficiency: Fetal and neonatal implications. Semin. Fetal Neonatal Med. 2013, 18, 129-135.

200. Brunvand, L.; Quigstad, E.; Urdal, P.; Haug, E. Vitamin D deficiency and fetal growth. Early Hum. Dev. 1996, 45, 27-33.

201. Gale, C.R.; Robinson, S.M.; Harvey, N.C.; Javaid, M.K.; Jiang, B.; Martyn, C.N.; Godfrey, K.M.; Cooper, C. Maternal vitamin D status during pregnancy and child outcomes. Eur. J. Clin. Nutr. 2008, 62, 68-77.

202. Agarwal, R.; Virmani, D.; Jaipal, M.L.; Gupta, S.; Gupta, N.; Sankar, M.J.; Bhatia, S.; Agarwal, A.; Devgan, V.; Deorari, A.; et al. Vitamin D status of low birth weight infants in Delhi: A comparative study. J. Trop. Pediatr. 2012, 58, 446-450. 
203. Gernand, A.D.; Simhan, H.N.; Klebanoff, M.A.; Bodnar, L.M. Maternal serum 25-hydroxyvitamin D and measures of newborn and placental weight in a U.S. multicenter cohort study. J. Clin. Endocrinol. Metab. 2013, 98, 398-404.

204. Ertl, R.; Yu, C.K.; Samaha, R.; Akolekar, R.; Nicolaides, K.H. Maternal serum vitamin D at 11-13 weeks in pregnancies delivering small for gestational age neonates. Fetal Diagn. Ther. 2012, 31, 103-108.

205. Namgung, R.; Tsang, R.C.; Specker, B.L.; Sierra, R.I.; Ho, M.L. Reduced serum osteocalcin and 1,25-dihydroxyvitamin D concentrations and low bone mineral content in small for gestational age infants: Evidence of decreased bone formation rates. J. Pediatr. 1993, 122, 269-275.

206. Van den Berg, G.; van Eijsden, M.; Vrijkotte, T.G.; Gemke, R.J. Suboptimal maternal vitamin D status and low education level as determinants of small-for-gestational-age birth weight. Eur. J. Nutr. 2013, 52, 273-279.

207. Scholl, T.O.; Chen, X. Vitamin D intake during pregnancy: Association with maternal characteristics and infant birth weight. Early Hum. Dev. 2009, 85, 231-234.

208. Mannion, C.A.; Gray-Donald, K.; Koski, K.G. Association of low intake of milk and vitamin D during pregnancy with decreased birth weight. CMAJ 2006, 174, 1273-1277.

209. Bodnar, L.M.; Catov, J.M.; Zmuda, J.M.; Cooper, M.E.; Parrott, M.S.; Roberts, J.M.; Marazita, M.L.; Simhan, H.N. Maternal serum 25-hydroxyvitamin D concentrations are associated with small-for-gestational age births in white women. J. Nutr. 2010, 140, 999-1006.

210. Kalra, P.; Das, V.; Agarwal, A.; Kumar, M.; Ramesh, V.; Bhatia, E.; Gupta, S.; Singh, S.; Saxena, P.; Bhatia, V. Effect of vitamin D supplementation during pregnancy on neonatal mineral homeostasis and anthropometry of the newborn and infant. Br. J. Nutr. 2012, 108, 1052-1058.

211. Young, B.E.; McNanley, T.J.; Cooper, E.M.; McIntyre, A.W.; Witter, F.; Harris, Z.L.; O’Brien, K.O. Maternal vitamin D status and calcium intake interact to affect fetal skeletal growth in utero in pregnant adolescents. Am. J. Clin. Nutr. 2012, 95, 1103-1112.

212. Diogenes, M.E.; Bezerra, F.F.; Rezende, E.P.; Taveira, M.F.; Pinhal, I.; Donangelo, C.M. Effect of calcium plus vitamin D supplementation during pregnancy in brazilian adolescent mothers: A randomized, placebo-controlled trial. Am. J. Clin. Nutr. 2013, 98, 82-91.

213. Morley, R.; Carlin, J.B.; Pasco, J.A.; Wark, J.D.; Ponsonby, A.L. Maternal 25-hydroxyvitamin D concentration and offspring birth size: Effect modification by infant VDR genotype. Eur. J. Clin. Nutr. 2009, 63, 802-804.

214. Jones, K.S.; Assar, S.; Harnpanich, D.; Bouillon, R.; Lambrechts, D.; Prentice, A.; Schoenmakers, I. 25(OH)D2 half-life is shorter than 25(OH)D3 half-life and is influenced by DBP concentration and genotype. J. Clin. Endocrinol. Metab. 2014, 99, 3373-3381.

215. McGrath, J.J.; Saha, S.; Burne, T.H.; Eyles, D.W. A systematic review of the association between common single nucleotide polymorphisms and 25-hydroxyvitamin D concentrations. $J$. Steroid Biochem. Mol. Biol. 2010, 121, 471-477.

216. Wang, T.J.; Zhang, F.; Richards, J.B.; Kestenbaum, B.; van Meurs, J.B.; Berry, D.; Kiel, D.P.; Streeten, E.A.; Ohlsson, C.; Koller, D.L.; et al. Common genetic determinants of vitamin D insufficiency: A genome-wide association study. Lancet 2010, 376, 180-188. 
217. Barry, E.L.; Rees, J.R.; Peacock, J.L.; Mott, L.A.; Amos, C.I.; Bostick, R.M.; Figueiredo, J.C.; Ahnen, D.J.; Bresalier, R.S.; Burke, C.A.; et al. Genetic variants in CYP2R1, CYP24A1, and VDR modify the efficacy of vitamin D3 supplementation for increasing serum 25-hydroxyvitamin D levels in a randomized controlled trial. J. Clin. Endocrinol. Metab. 2014, 99, 2133-2137.

218. Jones, K.S.; Assar, S.; Vanderschueren, D.; Bouillon, R.; Prentice, A.; Schoenmakers, I. Predictors of 25(OH)D half-life and plasma 25(OH)D concentration in the Gambia and the UK. Osteoporos. Int. 2014, doi: 10.1007/s00198-014-2905-0.

219. Karras, S.N.; Anagnostis, P.; Annweiler, C.; Naughton, D.P.; Petroczi, A.; Bili, E.; Harizopoulou, V.; Tarlatzis, B.C.; Persinaki, A.; Papadopoulou, F.; et al. Maternal vitamin D status during pregnancy: The mediterranean reality. Eur. J. Clin. Nutr. 2014, 68, 864-869.

220. Wuertz, C.; Gilbert, P.; Baier, W.; Kunz, C. Cross-sectional study of factors that influence the 25-hydroxyvitamin D status in pregnant women and in cord blood in Germany. Br. J. Nutr. 2013, 110, 1895-1902.

221. Wortsman, J.; Matsuoka, L.Y.; Chen, T.C.; Lu, Z.; Holick, M.F. Decreased bioavailability of vitamin D in obesity. Am. J. Clin. Nutr. 2000, 72, 690-693.

222. Abboud, M.; Puglisi, D.A.; Davies, B.N.; Rybchyn, M.; Whitehead, N.P.; Brock, K.E.; Cole, L.; Gordon-Thomson, C.; Fraser, D.R.; Mason, R.S. Evidence for a specific uptake and retention mechanism for 25-hydroxyvitamin D (25OHD) in skeletal muscle cells. Endocrinology 2013, 154, 3022-3030.

223. Abboud, M.; Gordon-Thomson, C.; Hoy, A.J.; Balaban, S.; Rybchyn, M.S.; Cole, L.; Su, Y.; Brennan-Speranza, T.C.; Fraser, D.R.; Mason, R.S. Uptake of 25-hydroxyvitamin D by muscle and fat cells. J. Steroid Biochem. Mol. Biol. 2014, 144, 232-236.

224. Josefson, J.L.; Feinglass, J.; Rademaker, A.W.; Metzger, B.E.; Zeiss, D.M.; Price, H.E.; Langman, C.B. Maternal obesity and vitamin D sufficiency are associated with cord blood vitamin D insufficiency. J. Clin. Endocrinol. Metab. 2013, 98, 114-119.

225. Bodnar, L.M.; Catov, J.M.; Roberts, J.M.; Simhan, H.N. Prepregnancy obesity predicts poor vitamin D status in mothers and their neonates. J. Nutr. 2007, 137, 2437-2442.

226. Crozier, S.R.; Harvey, N.C.; Inskip, H.M.; Godfrey, K.M.; Cooper, C.; Robinson, S.M. Maternal vitamin D status in pregnancy is associated with adiposity in the offspring: Findings from the Southampton Women's Survey. Am. J. Clin. Nutr. 2012, 96, 57-63.

227. Morales, E.; Romieu, I.; Guerra, S.; Ballester, F.; Rebagliato, M.; Vioque, J.; Tardon, A.; Rodriguez Delhi, C.; Arranz, L.; Torrent, M.; et al. Maternal vitamin D status in pregnancy and risk of lower respiratory tract infections, wheezing, and asthma in offspring. Epidemiology 2012, 23, 64-71.

228. Hossain, N.; Kanani, F.H.; Ramzan, S.; Kausar, R.; Ayaz, S.; Khanani, R.; Pal, L. Obstetric and neonatal outcomes of maternal vitamin D supplementation: Results of an open-label, randomized controlled trial of antenatal vitamin D supplementation in pakistani women. J. Clin. Endocrinol. Metab. 2014, 99, 2448-2455. 
229. Wagner, C.L.; McNeil, R.; Hamilton, S.A.; Winkler, J.; Rodriguez Cook, C.; Warner, G.; Bivens, B.; Davis, D.J.; Smith, P.G.; Murphy, M.; et al. A randomized trial of vitamin D supplementation in 2 community health center networks in South Carolina. Am. J. Obstet. Gynecol. 2013, 208, 137.e1-137.e13.

230. Sahu, M.; Das, V.; Aggarwal, A.; Rawat, V.; Saxena, P.; Bhatia, V. Vitamin D replacement in pregnant women in rural north india: A pilot study. Eur. J. Clin. Nutr. 2009, 63, 1157-1159.

231. Yu, C.K.; Sykes, L.; Sethi, M.; Teoh, T.G.; Robinson, S. Vitamin D deficiency and supplementation during pregnancy. Clin. Endocrinol. (Oxf.) 2009, 70, 685-690.

232. Grant, C.C.; Stewart, A.W.; Scragg, R.; Milne, T.; Rowden, J.; Ekeroma, A.; Wall, C.; Mitchell, E.A.; Crengle, S.; Trenholme, A.; et al. Vitamin D during pregnancy and infancy and infant serum 25-hydroxyvitamin D concentration. Pediatrics 2014, 133, 143-153.

233. Dawodu, A.; Saadi, H.F.; Bekdache, G.; Javed, Y.; Altaye, M.; Hollis, B.W. Randomized controlled trial (RCT) of vitamin D supplementation in pregnancy in a population with endemic vitamin D deficiency. J. Clin. Endocrinol. Metab. 2013, 98, 2337-2346.

234. Hollis, B.W.; Johnson, D.; Hulsey, T.C.; Ebeling, M.; Wagner, C.L. Vitamin D supplementation during pregnancy: Double-blind, randomized clinical trial of safety and effectiveness. J. Bone Min. Res. 2011, 26, 2341-2357.

235. Hashemipour, S.; Lalooha, F.; Zahir Mirdamadi, S.; Ziaee, A.; Dabaghi Ghaleh, T. Effect of vitamin D administration in vitamin D-deficient pregnant women on maternal and neonatal serum calcium and vitamin d concentrations: A randomised clinical trial. Br. J. Nutr. 2013, 110, 1611-1616.

236. Roth, D.E.; al Mahmud, A.; Raqib, R.; Akhtar, E.; Black, R.E.; Baqui, A.H. Pharmacokinetics of high-dose weekly oral vitamin D3 supplementation during the third trimester of pregnancy in Dhaka, Bangladesh. Nutrients 2013, 5, 788-810.

237. Shakiba, M.; Iranmanesh, M.R. Vitamin D requirement in pregnancy to prevent deficiency in neonates: A randomised trial. Singap. Med. J. 2013, 54, 285-288.

238. Hollis, B.W. Assessment and interpretation of circulating 25-hydroxyvitamin D and 1,25-dihydroxyvitamin D in the clinical environment. Endocrinol. Metab. Clin. North Am. 2010, 39, 271-286.

239. Volmer, D.A.; Mendes, L.R.; Stokes, C.S. Analysis of vitamin D metabolic markers by mass spectrometry: Current techniques, limitations of the "gold standard" method, and anticipated future directions. Mass Spectrom. Rev. 2015, 34, 2-23.

240. Zhang, S.W.; Jian, W.; Sullivan, S.; Sankaran, B.; Edom, R.W.; Weng, N.; Sharkey, D. Development and validation of an LC-MS/MS based method for quantification of 25 hydroxyvitamin D2 and 25 hydroxyvitamin D3 in human serum and plasma. J. Chromatogr. B Anal. Technol. Biomed. Life Sci. 2014, 961, 62-70.

241. Adaway, J.E.; Keevil, B.G.; Owen, L.J. Liquid chromatography tandem mass spectrometry in the clinical laboratory. Ann. Clin. Biochem. 2015, 52, 18-38.

242. Baecher, S.; Leinenbach, A.; Wright, J.A.; Pongratz, S.; Kobold, U.; Thiele, R. Simultaneous quantification of four vitamin $\mathrm{D}$ metabolites in human serum using high performance liquid chromatography tandem mass spectrometry for vitamin D profiling. Clin. Biochem. 2012, 45, 1491-1496. 
243. Shah, I.; Petroczi, A.; Naughton, D.P. Method for simultaneous analysis of eight analogues of vitamin D using liquid chromatography tandem mass spectrometry. Chem. Cent. J. 2012, 6, 112.

244. Higashi, T.; Goto, A.; Morohashi, M.; Ogawa, S.; Komatsu, K.; Sugiura, T.; Fukuoka, T.; Mitamura, K. Development and validation of a method for determination of plasma 25-hydroxyvitamin D3 3-sulfate using liquid chromatography/tandem mass spectrometry. J. Chromatogr. B Anal. Technol. Biomed. Life Sci. 2014, 969, 230-234.

245. Van den Ouweland, J.M.; Beijers, A.M.; van Daal, H. Overestimation of 25-hydroxyvitamin D3 by increased ionisation efficiency of 3-epi-25-hydroxyvitamin D3 in LC-MS/MS methods not separating both metabolites as determined by an LC-MS/MS method for separate quantification of 25-hydroxyvitamin D3, 3-epi-25-hydroxyvitamin D3 and 25-hydroxyvitamin D2 in human serum. J. Chromatogr. B Anal. Technol. Biomed. Life Sci. 2014, 967, 195-202.

246. Lee, S.; Oncescu, V.; Mancuso, M.; Mehta, S.; Erickson, D. A smartphone platform for the quantification of vitamin D levels. Lab Chip 2014, 14, 1437-1442.

247. Powe, C.E.; Evans, M.K.; Wenger, J.; Zonderman, A.B.; Berg, A.H.; Nalls, M.; Tamez, H.; Zhang, D.; Bhan, I.; Karumanchi, S.A.; et al. Vitamin D-binding protein and vitamin D status of black americans and white americans. N. Engl. J. Med. 2013, 369, 1991-2000.

248. Powe, C.E.; Karumanchi, S.A.; Thadhani, R. Vitamin D-binding protein and vitamin D in blacks and whites. N. Engl. J. Med. 2014, 370, 880-881.

249. Autier, P.; Boniol, M.; Pizot, C.; Mullie, P. Vitamin D status and ill health: A systematic review. Lancet Diabet. Endocrinol. 2014, 2, 76-89.

250. Bolland, M.J.; Grey, A.; Gamble, G.D.; Reid, I.R. The effect of vitamin D supplementation on skeletal, vascular, or cancer outcomes: A trial sequential meta-analysis. Lancet Diabetes Endocrinol. 2014, 2, 307-320.

251. Vitamin D: Chasing a myth? Lancet Diabetes Endocrinol. 2014, 2, 1; doi:10.1016/S2213-8587 (13)70164-5.

252. Gillie, O. Controlled trials of vitamin D, causality and type 2 statistical error. Public Health Nutr. 2014, doi:10.1017/S1368980014002304.

(C) 2015 by the authors; licensee MDPI, Basel, Switzerland. This article is an open access article distributed under the terms and conditions of the Creative Commons Attribution license (http://creativecommons.org/licenses/by/4.0/). 